NBER WORKING PAPER SERIES

\title{
CEO PAY AND THE RISE OF RELATIVE PERFORMANCE CONTRACTS: A QUESTION OF GOVERNANCE?
}

\author{
Brian Bell \\ John Van Reenen \\ Working Paper 22407 \\ http://www.nber.org/papers/w22407 \\ NATIONAL BUREAU OF ECONOMIC RESEARCH \\ 1050 Massachusetts Avenue \\ Cambridge, MA 02138 \\ July 2016
}

We thank Towers Watson for providing some of the data, although the views expressed are those of the authors and not Towers Watson. We have not accepted research funds from Towers Watson. This work was based on data from the Annual Survey of Hours and Earnings, produced by the Office for National Statistics (ONS) and supplied by the Secure Data Service at the UK Data Archive. The data are Crown Copyright and reproduced with the permission of the controller of HMSO and Queen's Printer for Scotland. The use of the data in this work does not imply the endorsement of ONS or the Secure Data Service at the UK Data Archive in relation to the interpretation or analysis of the data. This work uses research datasets which may not exactly reproduce National Statistics aggregates. This research was funded by the ESRC at the Centre for Economic Performance. The views expressed herein are those of the authors and do not necessarily reflect the views of the National Bureau of Economic Research.

NBER working papers are circulated for discussion and comment purposes. They have not been peer-reviewed or been subject to the review by the NBER Board of Directors that accompanies official NBER publications.

(C) 2016 by Brian Bell and John Van Reenen. All rights reserved. Short sections of text, not to exceed two paragraphs, may be quoted without explicit permission provided that full credit, including $(\odot$ notice, is given to the source. 
CEO Pay and the rise of Relative Performance Contracts: A Question of Governance?

Brian Bell and John Van Reenen

NBER Working Paper No. 22407

July 2016

JEL No. J33

\begin{abstract}
$\underline{\text { ABSTRACT }}$
Would moving to relative performance contracts improve the alignment between CEO pay and performance? To address this we exploit the large rise in relative performance awards and the share of equity pay in the UK over the last two decades. Using new employer-employee matched datasets we find that the CEO pay-performance relationship remains asymmetric: pay responds more to increases in shareholders' return performance than to decreases. Further, this asymmetry is stronger when governance appears weak. Second, there is substantial "pay-for-luck" as remuneration increases with random positive shocks, even when the CEO has equity awards that explicitly condition on firm performance relative to peer firms in the same sector. A reason why relative performance pay fails to deal with pay for luck is that CEOs who fail to meet the terms of their past performance awards are able to obtain more generous new equity rewards in the future. Moreover, this "compensation effect" is stronger when the firm has weak corporate governance. These findings suggest that reforms to the formal structure of CEO pay contracts are unlikely to align incentives in the absence of strong shareholder governance.
\end{abstract}

Brian Bell

Centre for Economic Performance

London School of Economics

Houghton Street

London WC2A 2AE

United Kingdom

b.bell1@1se.ac.uk

John Van Reenen

Department of Economics

London School of Economics

Centre for Economic Performance

Houghton Street

London WC2A 2AE

UNITED KINGDOM

and NBER

j.vanreenen@1se.ac.uk 


\section{INTRODUCTION}

In the wake of the slow recovery from the global financial crisis, CEO pay remains high on the political agenda just as it did following the Great Depression (Baker, 1939). The pay of CEOs and other senior executives has risen much faster than that of ordinary workers. Conyon et al. (2011) find that for S\&P500 firms, the average CEO made 31 times the wage of the average production worker in 1970 (26 times for the median CEO) but this ratio was 325 by 2008 (240 times for the median CEO). This ratio rose to 335 in 2015. ${ }^{1}$ Although the levels of pay are lower in the UK, the trend is similar to the US. Figure 1 shows that UK CEO pay was about 160\% larger in real terms in 2014 than 1999. This compares to about a $10 \%$ rise for the median worker and a $20 \%$ increase for those in the top $1 \%$. This continues a longer term trend: the ratio of median FTSE-100 CEO pay to median UK wages has risen from about 11 in 1980 to 96 in 2014. ${ }^{2}$

CEO pay could have risen purely because of competitive forces such as a stronger market for superstars caused by globalization and technological change (e.g. Gabaix and Landier, 2008; Rosen, 1981). But other factors may also play a role as attested by many corporate governance scandals. In this paper we re-visit the payperformance relationship for CEOs (and other employees). We use UK publicly listed firms as a case study because since the late 1990s, there has been a major shift towards rewarding CEOs based on relative performance. ${ }^{3}$ A typical plan is to grant executives equity conditional on improving shareholder returns relative to a "peer group" of large firms in the same sector (e.g. being among the top quartile of performers over a three year period). These relative performance contracts contrast to more standard US-style stock option contracts that are based on general improvements in equity prices.

It is surprising that such relative long-term incentive plans (LTIPs) are not more common since contracts based on relative performance are likely to be more efficient (Holmstrom, 1979, 1982). ${ }^{4}$ Relative performance plans are designed to reduce the

\footnotetext{
${ }^{1}$ http://www.aflcio.org/Corporate-Watch/Paywatch-2016

${ }^{2}$ Conyon, Gregg and Machin (1995) show that the median pay of the highest paid directors in FTSE-100 companies was $£ 63,000$ in 1980 , compared to median wages of $£ 5,400$. By 2014 , the median pay of this set of directors was $£ 2.61 \mathrm{~m}$ according to our data, while median wages had risen to $£ 27,215$.

${ }^{3}$ The move to relative performance plans arose from the recommendations of several high profile 1990s Commissions such as the 1995 Greenbury Report. http://en.wikipedia.org/wiki/Greenbury_Report. See also the 1992 Cadbury Report and 1998 Hampel Report.

${ }^{4}$ Using indirect methods relating relative firm to industry performance Gibbons and Murphy (1990) find some evidence for their use in large US firms in the 1970s and 1980s, but Aggarwal and Samwick (1999) find little evidence for them in the 1990s.
} 
problem that $\mathrm{CEO}$ remuneration could increase merely because of positive shocks to the firm unrelated to executive effort or ability. Figure 2 shows that at the start of our sample around a quarter of LTIPs had a sector component. This share almost doubled over the course of the 2000s. At the same time, the share of total pay that was accounted for by LTIP awards also doubled. US corporations have also been moving towards these plans, but at a slower rate. De Angelis and Grinstein (2016) report that although the trend is upwards, by 2007 only 30\% of S\&P 500 firms used some form of relative performance evaluation in at least part of their CEO pay package (Gong et al, 2011, estimate the figure to be $25 \%$ for wider group of S\&P 1500 firms). As an early adopter, the UK experience can shed light on the efficacy of such plans. Unfortunately, we find that relative performance contracts and other LTIPs (all of which have some performance condition attached to them) seem to have failed to solve the problems of aligning CEO and shareholder incentives.

We compile rich and original employer-employee panel data from several sources including confidential remuneration data from a global Human Resource Consultancy and administrative data on wages using social security identifiers. Focusing on the 500 publicly listed firms accounting for almost $90 \%$ of UK stock market value between 1999 and 2014 we present four main findings. First, there is a strong relationship between pay and performance for CEOs, especially when we improve our measures of pay to cover more aspects of CEO rewards (such as LTIPs). ${ }^{5}$ This is much less true for lower level employees where bonuses and other forms of incentive pay matter far less. Second, the CEO pay-performance relationship is asymmetric - pay responds more to increases in firm performance than to decreases. ${ }^{6}$ Third, this protection on the downside is only observed when there is weak external control (as proxied by lower institutional ownership and an explicit measure of corporate governance). Fourth, there is substantial "pay for luck" with CEO pay increasing when the industry experiences a random positive shock. This is even the case when the CEO is subject to relative sector LTIPs. We show that this is partly because CEOs in weakly governed firms who fail to meet the terms of their existing LTIPs obtain more generous deals on future LTIPs.

\footnotetext{
${ }^{5}$ Previously awarded but unvested equity awards generate a strong link between pay and performance. When we use more complete measures of pay, we unsurprisingly find an even higher elasticity.

${ }^{6}$ Garvey and Milbourne (2006) find some evidence of this in US data. Daniel et al (2016) claim to find no asymmetry when they use a wider definition of pay that includes all sources of shareholder wealth.
} 
One explanation for our findings is that CEO remuneration plans are sufficiently complex that shareholders have difficulty effectively monitoring the contracts. Our results suggest that reform of CEO pay is not achieved simply by altering the structure and terms of rewards. Governance matters more than formal contract structure, which implies that government policies to mandate contractual forms are likely to be gamed. Attention needs to be more focused on how to improve governance.

Our paper is in the CEO pay-performance tradition (Jensen and Murphy, 1990). Surveys by Frydman and Jenter (2010) and Bertrand (2009) conclude that there is a positive, statistically significant relationship between CEO pay and shareholder returns (and accounting measures of performance such as profitability and sales growth). This link exists for most time periods and across most countries, and there appears to have been an increase in the sensitivity of pay to performance over time as CEO compensation has tilted toward a more incentive-based structure (see Hall and Liebman, 1998). The interpretation of this empirical pay-performance link is more controversial. It may be the outcome of an optimal contract between principal and agent or it could, at least partially, reflect the exercise of managerial power to extract rents (e.g. Bebchuk and Fried, 2004; Djankov et al, 2008).

Various pieces of evidence suggest that corporate governance and external control matters for CEO pay. Hartzell and Starks (2003) show that institutional ownership concentration is positively related to the pay-performance elasticity and negatively related to the level of pay, whilst Core et al. (1999) find that the proportion of non-executives on the Board is associated with lower levels of CEO pay. ${ }^{7}$ Bertrand and Mullainathan (2001) find that their "pay for luck" effect is substantially attenuated when there is stronger external control - as measured by the number of large shareholders of the firm. This result has also been found in Garvey and Milbourn (2006). Some other papers have looked at the peer groups of firms used by corporations when they set CEO compensation. Faulkender and Yang (2013), for example, show that such peers are chosen strategically to drive up CEO pay, especially in the weakly governed firms (consistent with the results we will present below). However, these are generally not explicit contracts tied to relative performance, which is the focus of our paper.

\footnotetext{
${ }^{7}$ Ryan and Wiggins (2004) demonstrate that it is also associated with a stronger pay-performance link.
} 
The paper is structured as follows. Section II discusses data, Section III reports our main results, Section IV provides some extensions and robustness tests, while our conclusions are in Section V.

\section{DATA}

\section{II.A. Remuneration Data}

Our main data on pay comes from three sources: Boardex, Towers Watson (TW) and the Annual Survey of Hours and Earnings (ASHE). The Boardex database provides annual data from the Remuneration report of all listed-UK companies. This database is essentially the UK equivalent of the US ExecuComp database. The data cover all Board executives within the firm and reports base salary, cash and share bonuses, and details of all equity awards - regular stock options and Long-Term Incentive Plan awards. We supplemented this data by hand-collecting from the Annual Reports more detail on each equity award (e.g. grant date, performance condition, performance comparator group) and we also track each award through to vesting date to determine the outcome of the award. From these sources we define three alternative measures of pay (further details in Appendix A):

1. Cash Pay $=$ Salary + Bonus $($ Cash Bonus + Face Value of Deferred Bonus Shares)

2. New Pay $=$ Cash Pay + Expected Value at Grant Date of New Equity Awards (regular stock options and LTIPs)

3. Total Pay $=$ New Pay + Change in Expected Value of previously granted Equity Awards that have not yet been vested or exercised.

To give an idea of a typical LTIP award and how we value it ex ante consider the LTIP award made to the Vodafone CEO, Arun Sarin, on July 28th 2004 (see Figure 3). The CEO was awarded 2,016,806 shares in an LTIP share plan, with a face value of $£ 2.4 \mathrm{~m}$ (share price of $119 \mathrm{p}$ on the grant date). The 2005 annual report (which recorded the 2004 award) provides details of the vesting schedule and the set of firms that made up the comparison group (29 firms in the FTSE Global Telecom index). If the TSR of Vodafone over the subsequent three years was below the median of the comparison group, no shares would vest. TSR performance in the top quintile would result in full vesting, and a sliding (though not linear) scale operates between the median and $80^{\text {th }}$ 
percentile. In the event, on July $28^{\text {th }} 2007,576,806$ shares vested and $1,440,000$ were forfeit (i.e. $28.6 \%$ of the award vested) as TSR performance was in the $53^{\text {rd }}$ percentile. To value the award on grant date, we take the face value of the award and adjust downward for two effects. First, we use the history of all LTIP plans to determine the average vesting percentage - this gives us an approximate estimate of what probability the CEO should assign to actually obtaining the shares at vesting date ${ }^{8}$. Second, we adjust for the probability that the CEO will leave the firm during the performance evaluation period and thus lose the shares (or at best have them pro-rated). Appendix A discusses this in more detail and reports on various robustness tests. For regular stock options, we value using a standard Black-Scholes formula.

Our sample is comprised of the 300 largest publicly listed UK-domiciled firms each year from 1999 to 2014, representing on average 94\% of the market capitalization of the UK stock market. This gives a total sample of 498 firms. We then match these 498 firms to the Boardex database and obtain 472 matches with pay data, representing around $85 \%$ of total market capitalization. ${ }^{9}$ We have a final Boardex sample of 1,201 CEOs.

The second dataset we use is a proprietary remuneration survey conducted annually by Towers Watson (TW), one of the world's leading human resources consultants. TW survey a sample of large UK companies. The survey covers between 100-150 firms each year over the period 2001-2010. There are two advantages of the TW data over the published Boardex data. First, the TW survey provides us with extensive data on the pay of senior executives below the Board level. Reporting lines within the firm are used to generate management levels depending on the distance between the executive and the CEO. So "Level 1" are CEOs, "Level 2" are executives reporting directly to the $\mathrm{CEO}$, and so on. Firms choose how many levels down to report and the percentage of executives within a level to report. Discussions with TW confirm that coverage of Levels 1 and 2 within a firm is almost complete and Level 3 is also well represented. We combine all executives at Level 3 and below into one level since their average annual remuneration are broadly similar. For the sample used for which

\footnotetext{
8 Alternative assumptions about vesting probabilities such as using rolling or recursive historical outcomes or industry-specific outcomes does not substantively change any of our results.

${ }^{9}$ We fully match every firm to a Boardex identifier. The 26 firms without pay data are generally those that delisted at some point in 2001 or 2002 and appear not to have had their remuneration reports entered or archived by Boardex - see Appendix A for more details.
} 
we have at least two years of data, we have 163 CEOs, 1,605 Level 2 executives, and 4,531 Level 3 and below executives.

Another advantage of the TW data is that the valuation of all the components of pay are performed consistently by analysts at TW. Crucially, firms provide information on the exact structure of the LTIP awards (e.g. comparator measure, comparator group, vesting triggers and percentages etc.) which allows for the construction of an ex ante valuation of these important components of pay. To our knowledge this is the first paper that has been able to use externally-constructed expected values for these types of awards. On average, the TW sample places a $60 \%$ ex-ante valuation on the face value of such LTIP awards (which is close to the value we use in the Boardex sample based on historic vesting outcomes). ${ }^{10}$

The third dataset from which we compute all employee wages is ASHE. This is a sample of $1 \%$ of all employees in the UK based on the final two-digits of an individual's Social Security ("National Insurance") number. This is a mandatory administrative panel conducted in the first week of April in each year provided by employers. The data we use run from 2002-2014 and cover annual pay, including all cash-based forms of incentive and bonus pay. Importantly, from 2002, ASHE started to distinguish between base salary and bonuses, so we can decompose the effects of firm performance on both types of remuneration (Bell and Van Reenen, 2014). ${ }^{11}$

\section{II.B. Company Data}

Our various sources on pay are all matched together using firm-level identifiers. The final core sample contains 472 companies that have data from Boardex on the pay of CEOs. We are able to match to 327 of these in ASHE to have data on other workers in the same firm. This gives us a sample of 5,683 managers and 24,301 workers who are below the executive level. Finally, we have a subset of 126 firms for which we also have data from TW on the pay of a broader range of executives.

For all these firms we also have annual company account data and stock price data merged in from Thompson Datastream. These relate to the worldwide consolidated

\footnotetext{
${ }^{10}$ We cannot estimate Total Pay in the TW sample as previous awards are not consistently reported and nor are the vesting outcomes of previous awards.

${ }^{11}$ There is no data on share-based incentive plans in ASHE but this is unlikely to be a serious omission as ordinary UK workers receive virtually none of their pay in shares.
} 
activity of the firm and enable us to construct standard measures of firm performance such as shareholders' return, profitability and revenues per worker.

\section{II.C. Data Description}

Table 1 reports some summary statistics for the pay data. We report the mean and median level of new pay for each type of worker and break this total into the component parts. The Boardex data shows that the average total package for CEOs over the sample period was $£ 1.64 \mathrm{~m}$ (about $\$ 2.6 \mathrm{~m}$ ). As shown in Figure 1, this average masks a strong trend over the period, with average pay rising from $£ 0.9 \mathrm{~m}$ to $£ 1.9 \mathrm{~m}$. For the median CEO, base salary accounts for almost half of remuneration, with bonuses and new equity accounting broadly equally for the other half. Figure 2 shows that the share of new equity in annual pay has risen from around $15 \%$ to $30 \%$.

The Towers Watson data shows that the average total package for CEOs over the sample period was $£ 2.6 \mathrm{~m}$ (about $\$ 4.1 \mathrm{~m}$ ). Over the course of the decade, the average package rose from $£ 1.9 \mathrm{~m}$ in 2001 to $£ 3.1 \mathrm{~m}$ in 2010 . These figures are higher than the Boardex numbers since the companies covered tend to be larger and so have higher levels of CEO pay. As we move down the corporate hierarchy, the ratio of total pay from one level to the next drops significantly. So CEOs (Level 1) earn 205\% more than the next rung on the ladder (Level 2), and they in turn earn $153 \%$ more than the next rung (Level 3). ${ }^{12}$ In addition, the structure of pay changes as we move down the hierarchy. New equity accounts for $35 \%$ of CEO pay, but only $19 \%$ of those in Level $3+$ jobs. In contrast, cash bonuses account for around $30 \%$ of total pay for all levels of management.

The data from ASHE show the large gaps that exist between pay at the top of a company and that of the average worker. For those workers not in managerial positions average annual pay is around $£ 21,000$, of which of only $5 \%$ is bonus pay. ${ }^{13}$ This compares with average total expected remuneration for CEOs of $£ 1.64 \mathrm{~m}$, giving a payratio between the average $\mathrm{CEO}$ and average worker of 78 .

\footnotetext{
12 These figures can be compared to those reported in Main et al (1993) who have similar data on US executives over the period 1980-4. They estimate a ratio of $141 \%$ for CEOs and $75 \%$ for the next rung. It should be noted that they only have cash remuneration data. If we recalculate using this measure, our equivalent ratios are $139 \%$ and $115 \%$.

${ }^{13}$ The worker sample is restricted to those in the same job as 12 months ago earning at least $£ 4,000$ per year.
} 


\section{MAIN RESUltS}

\section{III.A. Firm-Level Pay-Performance Regressions}

Our basic estimation equations are of the form: ${ }^{14}$

$$
\ln (\text { pay })_{i j t}=\alpha_{i j}+\sum_{k=0}^{K} \beta_{k} \mathrm{PERF}_{\mathrm{jt}-\mathrm{k}}+\tau_{t}+\varepsilon_{i j t}
$$

where $\ln (\text { pay })_{\mathrm{ijt}}$ is the total remuneration of employee $i$ at firm $j$ at time $t$-as discussed above our empirical measures of pay includes salary as well as bonuses and equity pay. $\alpha_{i j}$ is an employee-firm match-specific fixed effect (hence absorbing both the time invariant employee and firm effect), $\tau_{t}$ are time dummies, $\varepsilon_{i j t}$ is an error term and $P E R F$ is the measure of firm performance - either total shareholder returns (TSR) as a measure of firm value or sales per head. The latter is sometimes used as a proxy for "quasi-rents" $(Q R)$ because in these regressions we control for the outside wage $\bar{w}$ through both the individual match effect and the time dummies. For the wage equations below CEO level we also control for the outside wage through average ln(wages) in the occupation by year cell and industry by year cell. We allow both for the contemporaneous association of pay and performance as well as lagged effects (our baseline specification is $K=2$, but we also experimented with alternative dynamic forms). The model is estimated by within groups (i.e. including a full set of firm by employee match effects) with standards errors clustered at the firm level (except when we use industry-level instrumental variables, where we cluster at the industry level). We also present specifications where we first-difference equation (1) instead of just including a full set of firm-employee match effects which is useful when we want to explore asymmetries of pay related to positive and negative performance.

Table 2 contains OLS estimates of equation (1) with total shareholder returns in Panel A and sales per employee in Panel B. The dependent variable is $\ln (\mathrm{New}$ Pay). These results are therefore identical to the standard pay-performance regressions in the CEO literature but now applied across the corporate hierarchy. We use our three different datasets and various corporate reporting levels. For brevity, we focus on the long-run elasticities reported from regressions including two lags of performance. In

\footnotetext{
${ }^{14}$ Several theoretical approaches can rationalize this empirical equation. We give examples in Appendix B.
} 
Panel A the pay-performance elasticity for the CEOs in the Boardex sample is estimated at 0.152 and is highly significant. ${ }^{15}$ The elasticity for CEOs in the TW sample (the larger firms) is substantially higher at 0.295 . The elasticity declines as we move down the corporate hierarchy with those in the next reporting level (Level 2) having an elasticity of 0.151 , about half as big as CEOs, with a further reduction as we move to the next level (0.116).

Focusing on the ASHE sample in the lower part of Panel A, we can see that there is a statistically significant elasticity of pay with respect to shareholder returns for non-managerial workers, but the magnitude of the coefficient (0.019) is tiny: an order of magnitude smaller than that observed for senior executives. For managers as a whole the pay-performance elasticity is more than twice as large as workers (0.051), but substantially smaller than that for CEOs and other senior executives.

Panel B of Table 2 uses sales per worker as an alternative measure of firm performance. We assume that the outside wage for all executives is captured by the aggregate time dummies (i.e. a common pool for talent), while for managers we control for the two-digit industry average wage and for workers both the two-digit industry and two-digit occupation average wage. ${ }^{16}$ Once again, we find a strong positive correlation between executive pay and firm performance. For example, in the TW sample for CEOs the long-run elasticity is estimated to be 0.374 , falling to 0.219 for the level immediately below. As with Panel A, we find elasticities of about 0.02 for non-managers, with the average managerial elasticity about twice this size. All these findings are robust to examining a larger sample of firms including those who are not listed on the stock exchange (see Appendix C).

\section{III.B. Firm Performance and Components of Pay}

In Table 3 we decompose New Pay into base salary, bonus and the expected value of new equity and estimate equation (1) separately for each component of pay. ${ }^{17}$ Panel A

\footnotetext{
15 This is somewhat higher than other UK estimates. Conyon et al. (2011) have an estimate of 0.096 over the period 2003-08 and Ozkan (2009) reports an estimate of 0.093 over the period 1999-2005.

${ }^{16}$ We have also experimented with (i) adjusting sales for industry-level intermediate cost shares and (ii) using more disaggregated industries, but this has little effect on our estimates. This model is similar to that estimated by Card et al. (2014), though they specify the rents variable in levels rather than logs and include capital per head.

${ }^{17}$ Note that because both bonuses and incentive pay are zero for some workers we add $£ 1$ to the dependent variable to allow us to take logs (recall also that we only observe the first two components of pay in the ASHE data). The results are qualitatively similar if the dependent variable is the absolute amount of
} 
shows that the pay-performance link is mainly driven by the responsiveness of bonuses and new equity awards to shareholder returns. In the Boardex sample, there is essentially no relationship between base salary and performance. In contrast, there is a sizeable link with bonuses - a $10 \%$ rise in shareholder returns is associated with a $17 \%$ rise in the level of the bonus. The responsiveness of bonuses to performance declines monotonically across the corporate hierarchy. The effect of firm performance on new equity pay is substantially smaller, though still significant. This is consistent with the view that firms set target share incentive awards primarily as a multiple of base salary and do not explicitly allow current performance to influence the level of such awards. In contrast, bonuses are often explicitly justified in terms of contemporaneous performance. Interestingly, when we use the ASHE data to disaggregate the annual pay of managers and workers into base salary and cash bonus we observe the same pattern as in the CEO and executives sample. Salary across managers and workers is unrelated to shareholder returns, while bonuses are positively related to firm performance for all workers. The coefficients imply that workers' bonuses rise by $7.5 \%$ for every $10 \%$ improvement in shareholder returns, and managers' bonuses rise by $14 \%$.

In Panel B of Table 3 we again use sales per employee as an alternative measure of firm performance to TSR. The results are broadly similar, though the coefficients in the TW sample are imprecise. But as with the TSR results, we find that the payperformance link occurs primarily through its effects on the incentive elements of pay. Indeed, in both the Boardex and ASHE samples it is striking how strong the links are between sales per worker and bonuses. ${ }^{18}$

\section{III.C. Asymmetrical Response of Pay to Performance?}

Does the CEO pay-performance relationship purely reflect market forces or are there corporate governance issues? We investigate this in two ways. First we look at asymmetric responses in the pay-performance relationship, then in sub-section III.D we look at the evidence of "pay for luck".

\footnotetext{
salaries, bonus or incentive pay instead of the logged values. Increases in firm performance are associated with a significant increase in the share of bonuses in total pay.

${ }^{18}$ Why did we find little effect on workers' overall pay from firm performance in Table 2 if we observe strong effects on bonuses in Table 3? The simple answer is that workers do not receive much of their pay in bonuses. For the average worker, only $5 \%$ of pay is accounted for by bonuses (see Table 1). So a $10 \%$ rise in shareholder returns translates into only about a $0.4 \%$ rise in overall pay.
} 
The idea behind the examination of asymmetry is whether CEO pay increases with positive firm performance, but decreases by far less when performance declines. Furthermore, we are interested in whether this asymmetry is particularly strong when governance is weak. Our main proxy for governance is the impact of external shareholder control. Numerous studies have argued that pay in the boardroom is related to measures of corporate governance such as the proportion of independent directors or the existence of an independent remuneration committee. Aghion, Van Reenen and Zingales (2013) argue that institutional ownership is associated with better governance (as measured for example by the Gompers et al. (2003) IRRC index), because activist institutions such as pension funds typically have the ability and incentive to monitor CEOs more than dispersed owners. Our data on institutional ownership comes from Thomson Reuters Global Ownership files. The data we use relates to December of each year from 1997 and records the percentage of outstanding shares owned by all those with a shareholding larger than $0.015 \%$. We calculate for each year the percentage of outstanding shares held by institutional investors. Across the sample as a whole, institutional investors account for $60 \%$ of share ownership - roughly the same as observed for the U.S. in the 2000s (Aghion et al., 2013). There is however significant variation across companies, with a standard deviation of $19 \%$. We split the sample into quartiles based on average institutional ownership and focus on the difference between the lowest quartile of ownership (less than 48\%) and the other three quartiles. ${ }^{19}$

First, we examine whether the estimated pay-performance link differs depending on institutional ownership. Column (1) of Table 4 repeats the basic CEO fixed-effect TSR regression from Table 2 for the slightly reduced sample for which we also have institutional ownership data. It shows an almost identical coefficient to the within group estimate of Table 3 (0.149 compared to 0.147). In column (2) we switch to a first-difference specification since we will subsequently want to examine asymmetries in the pay-performance relationship depending on whether returns are positive or negative and this is more naturally specified in first-differences. The coefficient in the first-difference specification is very close to that in the fixed-effect model.

\footnotetext{
${ }^{19}$ Nothing hinges on using quartiles or combining the highest three quartiles into one category. Results available on request show that the remaining three quartiles have very similar estimated coefficients and one cannot reject equality. Table A4 shows that there is little evidence of significant differences between the low and high institutional ownership groups across observables such as sales, employment, market capitalisation or executive pay levels or growth rates.
} 
Column (3) of Table 4 allows for an interaction between returns and whether the firm has high or low institutional ownership. ${ }^{20}$ The link between pay and performance is much larger (and significant) for the high institutional ownership firms (0.227) than the low institutional ownership firms (0.030). In the next column we allow different pay-performance elasticities between positive and negative shareholder returns, by including an interaction between returns and an indicator equal to 1 if the growth was positive $(\Delta \ln \mathrm{TSR}(+))$ and zero otherwise. Column (4) shows that there appears to be a marginally significant (and economically substantial) propensity to reward positive returns more favourably than negative returns are penalized looking at all firms together.

Column (5) of Table 4 generalizes the column (4) specification to allow the asymmetry of pay and performance to depend on our proxies for corporate governance. We find evidence that there is a significant asymmetry for the more "weakly governed" firms but not the strongly governed firms. We find that firms with weak governance reward positive returns with significantly higher pay (an elasticity of $0.298=0.430-$ 0.132 ) but require no pay penalty for negative returns (an insignificant -0.132). In other words, for such firms the coefficients imply that a $10 \%$ increase in TSR is associated with $3 \%$ higher pay, whereas a $10 \%$ decrease has no significant penalty (if anything, a $1.3 \%$ gain). By contrast, the firms with higher institutional ownership appear to reward performance symmetrically (as the coefficient of -0.037 on the interaction is insignificant).

Figure 4 uses the coefficients from column (5) of Table 4 to illustrate this asymmetry for the high and low institutional investor categories separately. There appears to be a clear symmetry for Panel A (high institutional ownership) compared to Panel B (low institutional ownership) where CEOs do not seem to be "punished" for poor performance.

All these results relate to New Pay (i.e. salary plus bonus plus expected value of new equity awards). The asymmetry result is driven by the new equity awards since regressions that use cash pay (i.e. salary plus bonus) as the dependent variable do not

\footnotetext{
${ }^{20}$ All regressions with institutional ownership effects also include a full set of interactions between the ownership dummies and the time dummies. The measure of institutional ownership is always lagged one period.
} 
show this asymmetry. ${ }^{21}$ This is important since our results below will also point to the use of new awards to circumvent the relative performance contracts.

Institutional ownership is not a perfect proxy for governance, of course (e.g. Schain and Stiebale, 2016), so we also consider an alternative measure of governance by using data from the Institutional Voting Information Service (IVIS). IVIS provides a detailed analysis of UK-listed companies in relation to the level of compliance with corporate governance "best practice" (see Selvaggi and Upton, 2008, for more details $^{22}$ ). Its main purpose is to assist subscribers with their voting decisions at the annual general meeting (e.g. approving the accounts, dividends, elections and remuneration of directors). IVIS draws up a list of key issues for investors to consider and highlights their seriousness using a colour-coded system. A "red-top" is used to indicate the strongest concern that a proposal does not comply with best practice, an "amber-top" indicates concern and a "blue-top" indicates no area of major concern. We use IVIS data from 1998-2014 and code a red-top as a 2, an amber-top as a 1 and a blue-top as a $0 .{ }^{23} \mathrm{We}$ average this score across the firm and split firms into "well governed" if this score is above the median and "poorly governed if the score is below the median. In column (6) of Table 4 we use the IVIS measure as our indicator of corporate governance. Again, we cannot reject symmetry of the CEO pay-performance relationship for well-governed firms (a coefficient of -0.093 with a standard error of 0.067), whereas we do reject it for the poorly governed firms (a coefficient of 0.249 with a standard error of 0.094).

To check that these results are driven by governance and not some other correlated effect (like firm size), we repeated the analysis of Table 4 looking at interactions with other observables. For example, we constructed dummy variables based on whether the firm is in the lowest quartile or below median based on market capitalization, total employment, shareholder returns and lagged levels of CEO pay. In no case do we observe significant evidence of asymmetry in pay with respect to performance on any of these alternative categorizations.

\footnotetext{
${ }^{21}$ Although they do still show a stronger link between pay and performance for higher institutional ownership firms

${ }^{22}$ The authors also use a subset of this data to examine the link between corporate governance and shareholder returns (in the spirit of Gompers et al., 2003)). They find that the shares of the well-governed firms have higher shareholder returns.

${ }^{23}$ This captures the fact that red-tops are substantially less-likely than amber-tops and thus signify significantly more concern. In our data, $8 \%$ of our observations are red-topped, and $21 \%$ are ambertopped. Our results are robust to using a $1 / 0$ categorization instead.
} 
Overall, we conclude that there is an asymmetry in rewards, with more benefits on the upside than the downside, driven by those firms with weak governance. ${ }^{24}$

\section{III.D. CEO Pay for Luck: Instrumental Variable (IV) strategies}

Another way to investigate the issue of whether the pay-performance relationship is all due to market incentives is to consider the extent to which CEOs are rewarded for luck. Consider the pay of oil company CEOs. Their pay is related to their firm's shareholder returns, but this in turn is strongly correlated with the price of oil. Since the oil price is easily observed and outside the control of the CEO, the standard Holmstrom and Milgrom (1987) result would argue that the firm should ensure no link between pay and the oil price. But in practice, the link is strong suggesting that CEOs are being partly rewarded for luck. Bertrand and Mullainathan (2001) show that US CEOs receive the same payoff to a "lucky dollar" of shareholder returns as they do to a general dollar of shareholder returns. Formally this is illustrated by showing that the OLS estimate of the pay-performance elasticity is the same as the IV estimate using industry performance to instrument for firm performance. ${ }^{25}$ Since the CEO cannot control industry performance, we can interpret the IV estimate as identifying those returns that are common to the industry i.e. luck. ${ }^{26}$

We follow this idea by instrumenting shareholder returns with the returns in the global industry (the Datastream Industrial Sub-Sector Global-ex-UK Index) but dropping the UK firms from this index to avoid a mechanical relationship (i.e. we construct the leave-out mean). For our 471 firms we have 92 such sub-sectors (we lose one firm for which we cannot match a global industry index). Column (1) of Table 5 uses Cash Pay (equal to salary plus bonus) as the dependent variable, while column (2) uses New Pay, which is cash plus the expected value of new equity awards (the measure

\footnotetext{
${ }^{24}$ This result is in the same spirit as Harford and $\mathrm{Li}$ (2007) who find evidence that CEOs pursue excessive mergers and acquisitions to disguise under-performance and hence help break the pay-performance link. ${ }^{25}$ Many other instruments have been suggested in the literature. Blanchflower et al. (1996) focus on using lag structures, but potential external instruments have included firm-specific technological innovation (Van Reenen, 1996), import/export price shocks (Abowd and Lemieux, 1993, and Bertrand, 2004) and oil price shocks (Bertrand and Mullainathan, 2001). Card et al. (2014) instrument the valueadded per worker of each firm (their measure of rents) by the value-added per worker of all firms in the same four-digit industry outside the region of Italy on which their analysis is conducted. The identifying assumption is then that industry demand shocks affect firm-level profitability but have no direct effect on local labour supply.

${ }^{26}$ Subsequent work has examined whether the pay-for-luck effect is asymmetric. Garvey and Milbourn (2006) show that CEO pay rises when firm performance increases due to good luck but does not go down to the same extent when firm performance decreases due to bad luck. By contrast, Daniel et al (2016) argue that this apparent asymmetry is a result of not controlling for firm size.
} 
used in Tables 2 and 4). The coefficient on TSR is significant in both specifications and interestingly, the OLS and IV estimates are similar regardless of which pay concept is used. We cannot reject that the IV and OLS estimates in every column of Table 5 are equal at the $5 \%$ significance level.

In column (3) of Table 5 we use Total Pay as the dependent variable, which adds to New Pay the change in value of unexercised and unvested equity awards granted in previous years. The longer a CEO remains in their job, the quantitative significance of these prior awards rises. For every equity-based award (deferred shares, regular stock options, LTIPs) we record the grant-date information and then follow the award across subsequent annual reports to determine the ultimate outcome of the award (whether the original award vests and if so how much, and whether the vested award has been exercised). We then compute the annual revaluation of all previous equity awards that have not yet reached their vesting date. Since the value of past awards is, at least in part, mechanically related to shareholder returns, it is unsurprising that in column (3) the coefficient on TSR increases substantially. This indicates that the pay-performance link is tighter than would be suggested by less comprehensive pay measures (as Hall and Liebman, 1998, also found for the US). Again though, the IV estimate is similar to the OLS. $^{27}$

So across all columns in Table 5, CEO "pay for luck" appears very prevalent, just as in Bertrand and Mullainathan $(2001)^{28}$.

\section{III.E. Do Sector LTIPs eliminate Pay for Luck?}

The evidence of substantial CEO pay hikes from movements in the industry TSR may appear surprising. The substantial corporate reforms in the UK in the late 1990s were supposed to explicitly control for improvements in the firm position that were due to industry-wide shocks. So is it simply that the reforms failed in this objective or is something more complex going on? An obvious starting point is to focus on those LTIPs with an explicit sector performance hurdle. At a minimum we would expect such awards to exhibit much less sector pay-for-luck. Thus for all LTIP awards, we identify

\footnotetext{
${ }^{27}$ If we were to add in the shares held voluntarily in the CEO's portfolio as a measure of "pay" the relationship would strengthen even further of course.

${ }^{28}$ We have also investigated whether the pay-for-luck effect is larger in less well-governed firms. If we take the estimates in Column (3) of Table 4 and instrument returns allowing for a differential effect between strong and weak governance, we do find that the pay-performance elasticities are much closer when instrumenting than in the OLS specification. This is consistent with such an interpretation, though the effect is not statistically significant.
} 
those that have at least some part of the award that vest only on the performance of shareholder returns relative to a sector benchmark. We term these sector LTIPs (and their converse non-sector LTIPs).

We now conduct the OLS/IV comparison of the previous sub-section for two outcomes: (1) the percentage of the LTIP award that ultimately vests and (2) the change in value of the LTIP from grant date to vest date. We are interested in the extent to which these two outcomes for CEOs successfully condition out the sector pay-for-luck (i.e. the OLS coefficient being significantly larger than the IV coefficient). Table 6 reports the results. In Panel A, the results show that the percentage of the LTIP that ultimately vests is strongly correlated with firm returns as one would expect. When we instrument firm returns with sector returns in column (2), the IV coefficient for sector LTIPs drops substantially and is no longer significant at the $5 \%$ level. ${ }^{29}$ By contrast, the non-sector LTIP IV coefficient is indistinguishable from the OLS coefficient - so as we would expect, these LTIPs fail to condition out sector luck. Turning to Panel B however, we find that when we focus instead on the change in value of the LTIP from grant date to vest date, the sector LTIPs continue to reward sector luck to a significant extent - though even here there is attenuation of the sector luck component for sector LTIPs (column (2)) whereas this is not the case for non-sector LTIPs (column (4)).

Why do sector LTIPs seem to successfully remove most pay-for-luck in the probability of vesting but seem to do so much less successfully for the more important issue of overall pay? One reason may be that other components of pay are used to offset any penalty for the CEO associated with LTIPs failing to meet their performance hurdles. To test this hypothesis, we focus on the LTIPs that reach their vesting date and see whether there is any reaction to these events. The actually vesting outcome is fully known at the time to the firm. Suppose in a given financial year $t$ there are a set of LTIPs, $S_{V}$, that reach their vesting date. For each of the LTIPs in this set, we can calculate the percentage of originally granted shares that actually vest. This is bounded between 0 and 1 . If we have more than one LTIP in the $\mathrm{S}_{\mathrm{V}}$ set, we can calculate a weighted percentage using the expected value at grant date as weights. We can then

\footnotetext{
${ }^{29}$ It would be surprising for the estimated IV coefficient to fall to zero even if the sector LTIP perfectly conditioned out sector luck. There are two key reasons for this. First, our sector instrument is not in general the exact sector comparator group used in the evaluation (this is because the benchmark firms are not always revealed in the company accounts). Second, we define a sector LTIP as one with at least some sector-return comparison. However such an LTIP will in general have other comparators as well that will not completely condition out sector luck.
} 
define a dummy variable, LTIP_Fail equal to 1 if this vesting percentage is less than 1 (i.e. not full vesting). We use the one-year lag of this indicator since the firm may not know for certain what will happen to the LTIPs that are vesting this year (so will not be certain of the value of LTIP_Fail). But they will definitely know the previous year's outcome.

Table 7 reports the results of including such an indicator variable in the usual pay-performance regressions. We consider two of our measures of pay. First, using $\ln$ (New Pay) as the dependent variable allows for offsetting compensation across all components of pay. Second, we use the value of new equity awards only to test whether firms use new LTIP awards to offset any decline in the value of previously awarded LTIPs. Thus we can compare the coefficients across the two measures of pay to determine whether and where any such compensation is occurring.

Column (1) of Table 7 reports the coefficient estimates where the dependent variable is $\ln$ (New Pay), showing that there is no obvious link between pay and whether LTIPs failed in the previous year. We then decompose this into cash pay (salary plus bonus) in column (2) and new equity awards in column (3). Like the first column, CEO cash does not respond to past failure of LTIPs, but in contrast, the coefficient on Lagged_LTIP_Fail is positive, though not significant, for New Equity Awards. Note that all our regressions include $\ln (\mathrm{TSR})$ on the right-hand side, so we control for the fact that declines in the value of previous awards usually occur in years that see declines in shareholder returns. Of course the sign of the coefficient on Lagged_LTIP_Fall goes the wrong way for this to be an explanation - we would expect pay to be lower in poor performing years.

Does corporate governance matter here? To assess this, we interact the "failed LTIP" indicator with our main indicator of corporate governance (institutional ownership). Columns (4) and (5) replicate the previous columns but allow for this potential governance asymmetry. The key result can be seen in column (5). Echoing the results of Table 4, we find that firms with low institutional ownership provide significantly higher compensation (in the form of new equity awards) when previous LTIPs fail. This is not the case in firms with high institutional ownership and the difference of coefficients $(143,486$ vs. 9,363$)$ is significant ( $p$-value $=0.047$ ). There is no pay offset for well-governed firms implying that external control matters for CEO pay. 
This evidence suggests that LTIPs are being undermined in some firms. In firms with poor governance, when LTIPs do not pay out, CEOs are able to obtain significantly better deals for their new LTIPs to compensate them for their failure to meet the terms of their existing relative performance contracts.

\section{EXTENSIONS AND ROBUSTNESS}

\section{IV.A. Other reasons for pay for luck in sector LTIPs}

In addition to poor governance there is also a mechanical reason for the "pay for luck" aspect of sector LTIPs. Sector LTIPs explicitly rank on sector performance to determine vesting and thus by definition remove sector luck from this outcome. However, conditional on vesting, the change in value of a sector LTIP depends only on the firm return, which includes sector luck. An example makes this clear. Suppose a CEO is given a sector LTIP with an initial face value of $£ 3 \mathrm{~m}$ (say $1 \mathrm{~m}$ shares at a grant price of £3) and that the firm ultimately ranks in the top quartile against the sector comparators. So the LTIP fully vests and the CEO gets the $1 \mathrm{~m}$ shares. But consider two possible ways that this happened. First, suppose the firm outperformed a strongly performing sector (the firm returns were $50 \%$ compared to a sector average of $40 \%$ ) and in the second the firm outperforms a poorly performing sector (firm returns of $-30 \%$ against a sector average of $-40 \%$ ). In the first case, the vested LTIP has an ex-post value of $£ 4.5 \mathrm{~m}$ while in the second it has a value of $£ 2.1 \mathrm{~m}$. So although the relative performance against the sector is the same in both cases, the change in value is much higher in the strongly performing sector example. Thus, pay-for-luck remains an integral part of the sector LTIP structure and helps explain the results of Table 6. An alternative structure for such awards would be to grant the CEO a notional award of $£ 3 \mathrm{~m}$ and on successful vesting adjust the amount paid by the excess return of the firm relative to the sector return. This would remove all the pay-for-luck element. ${ }^{30}$ We suggest that moving to such an LTIP structure would be preferable from an incentives perspective than the current state of affairs.

\footnotetext{
${ }^{30}$ In Appendix C we present a simulation to show the effect of such an LTIP structure relative to the current state of affairs.
} 


\section{IV.B. Firm Performance and Job Exit}

Our estimates implicitly assume that the executive remains with the firm and so is in a position to have their pay respond to changes in firm performance. It is plausible however that poor performance may lead not only to lower wages but also to an increased probability of a job separation (e.g. Huson et al, 2001; Jenter and Kanaan, 2010). Thus we may be underestimating the impact of firm performance on CEO expected returns. To examine this issue, we estimate job-exit probabilities for executives and workers. ${ }^{31} \mathrm{We}$ define a job-exit as occurring subsequent to the last observed pay year for an individual with a particular firm, provided we observe the same firm in the following year but without the individual employed. Table A6 reports the marginal probabilities of job-exit for CEO's and workers as a function of changes in shareholder returns. For CEOs we find strong negative effects from shareholder returns. In other words, poor firm performance is associated with an increased risk of job-exit. ${ }^{32}$

This raises the issue of whether our results are biased due to dynamic selection (the static effects are controlled for by the match specific effects). Maybe the asymmetry of the coefficient on shareholder returns in the CEO pay equation in Table 4 could be due to attenuation as large negative shocks to shareholder returns are followed by dismissal rather than compensation cuts? To look at this issue we performed several tests. First, we re-ran Table 4 excluding the last year (or alternatively the last two or three years) of CEO tenure. The asymmetries we identify in Table 4 continue to hold for this sub-sample. Secondly, we allowed for an asymmetry in the job-exit probability with respect to shareholder returns. However, unlike CEO pay, we found no significant difference between the impact of positive or negative returns on job-exits. Thirdly, we allowed for both the level effect of shareholder return on exit and

\footnotetext{
${ }^{31}$ Since the TW sample varies from year to year it is difficult to identify the exact year of departure for any executive. The problem is that a firm may, for example, be in the TW data in 2001 and 2003 but not 2002. If the executive is in the 2001 survey but not the 2003 survey we cannot date the final pay year since we do not know whether he was still with the firm in 2002. The Boardex data does not have this attrition problem as we observe every consecutive year. As a result we only present results for the Boardex data which covers all years and the ASHE data for workers.

${ }^{32}$ Although our data cannot distinguish between voluntary and involuntary job-exits, Gregory-Smith et al. (2009) show that for a broadly similar group of UK CEOs over the period 1996-2005, there is a strong effect on job-exits from shareholder returns. Furthermore, they conducted a news search of reasons for exit to identify exits due to dismissal. Unsurprisingly, the effect of poor shareholder returns is observed most strongly for those CEOs who are forced to leave.
} 
its asymmetry with positive and negative TSR realisations to vary with our corporate governance measures. Again, we could find no significant differences of these on job exit. Hence, it seems unlikely that the findings on the CEO pay-performance relationships we describe in this paper are purely due to dynamic selection bias.

\section{IV.C Other Robustness Tests}

We subjected our results to a number of other robustness tests (see Appendix C). First, we examined whether the coefficients changed over time. We could not reject the hypothesis that the coefficient on the pay-performance elasticity was stable. ${ }^{33}$ Second, we examined whether the pay-performance relationship was different in finance than other sectors given the high attention to bankers' pay in recent years. Including a TSRfinance interaction in the Boardex regressions of column (1) Table 2 produced a coefficient (standard error) of $0.010(0.048)$ which does not suggest some greater payperformance sensitivity for financial services.

\section{CONCLusions}

Using rich and original matched firm-employee data we have shown that there is a strong link between firm performance and the pay of CEOs (and other senior executives), but much weaker and economically small links with average worker pay. Base salary tends to be unresponsive to firm performance, while incentive pay (bonuses and LTIPs) are very responsive. Not all of this CEO pay-performance relationship is likely to be due to purely competitive reasons. First, the response to performance is asymmetric: CEO pay rises much more when the firm does well, than it falls when the firm does badly. Further, this asymmetry occurs only for firms with weaker governance (as proxied by low levels of institutional ownership and IVIS based measures of corporate governance). Second, there remains substantial pay-for-luck with pay responding to industry-wide improvements in performance. Third, even when CEO pay is explicitly tied to performance relative to sector averages, it seems to have little effect on reducing pay for luck. In part, this is because when CEOs fail their relative performance contracts, they are compensated by even more generous incentive pay

\footnotetext{
${ }^{33}$ For example, if we define a dummy equal to one if after 2007 (and zero otherwise), the middle of our sample and re-estimating the Table 2 column (1) coefficient for Boardex (0.147) including a TSR interaction with this dummy, the coefficient is -0.007 and insignificant.
} 
deals. And again, these rewards for failure are concentrated in those firms that have weaker governance.

We have suggested ways in which relative LTIPS could be restructured to improve incentives by making them less non-linear. But the more fundamental problem is that CEO remuneration packages are so opaque and complex it is hard for individual shareholders to gauge their true structure and generosity unless they are unusually assiduous and strongly motivated. Greater forced transparency is unlikely to resolve this (e.g. Mas, 2016; Hermalin and Weisbach, 2012). Institutional owners, because they have greater resources and larger block-holdings, are more likely agents to have the ability and incentive to be active monitors. In the absence of such agents "stepping up to the plate", however, it is likely that calls for cruder and more direct intervention in CEO pay will become stronger over time. 


\section{REFERENCES}

Abowd, J. M., and Lemieux, T. (1993) "The Effects of Product Market Competition on Collective Bargaining Agreements: The Case of Foreign Competition in Canada", Quarterly Journal of Economics, 108, 983-1014.

Aggarwal, R. and A. Samwick (1999) "The other side of the trade-off: The impact of risk on executive compensation" Journal of Political Economy, 107, 65-105

Aghion, P., Van Reenen, J., and Zingales, L. (2013) "Innovation and Institutional Ownership", American Economic Review, 103(1): 277-304.

Baker, J. (1939) "Executive Compensation Payments by Large and Small Industrial Firms" Quarterly Journal of Economics, 53(3), 404-434

Bebchuk, L. and Fried, J. (2004) Pay without Performance: The Unfulfilled Promise of Executive Compensation, Cambridge: Harvard University Press

Bell, B. and Van Reenen, J. (2014) "Bankers and their Bonuses", Economic Journal 124 (574) F1-21.

Bertrand, M. (2004) "From Invisible hand to the invisible handshake? How import competition changes the employment relationship" Journal of Labor Economics, 22(4), 723-765.

Bertrand, M. and Mullainathan, S. (2001) "Are CEOs rewarded for luck? The ones without principals are", Quarterly Journal of Economics, 116, 901-32.

Bertrand, M. (2009) “CEOs”, Annual Review of Economics, 1, 121-50.

Blanchflower, D., Oswald, A., and Sanfey, P. (1996) "Wages, Profits and Rent Sharing", Quarterly Journal of Economics, 111, 227-52.

Card, D., Devicienti, F., and Maida, A. (2014) "Rent Sharing, Hold Up and Wages: Evidence from Matched Panel Data", Review of Economic Studies, 81(1), 84111 .

Conyon, M., Fernandes, N., Ferreira, M., Matos, P., and Murphy, K. (2011) "The Executive Compensation Controversy: A Transatlantic Analysis", in Tito Boeri, Claudio L. and K. Murphy (eds) Executive Remuneration and employee Performance Related Pay, Oxford: Oxford University Press, 116-122

Conyon, Martin, Gregg, Paul, and Machin, Stephen (1995) "Taking care of business: Executive Compensation in the United Kingdom", Economic Journal, 105(430), 229-47.

Core, John, Robert Holthausen, and David Larcker (1999) "Corporate governance, chief executive officer compensation, and firm performance", Journal of Financial Economics, 51, 371-406.

Daniel, Naveen, Yuanzhi Li, and Lalitha Naveen (2016) "Asymmetry in Pay for Luck: A Size Effect?" mimeo, Drexel University.

De Angelis, David and Yaniv Grinstein (2016) "Relative Performance Evaluation in CEO Compensation: A Non-Agency Explanation" mimeo, Cornell

Djankov, S., R. La Porta, F. Lopez-de-Silanes and A. Shleifer (2008) "The Law and Economics of Self-dealing" Journal of Financial Economics, 88(3), 430-465

Faulkender, M. and J. Yang (2013) "Is disclosure an effective cleaning mechanism? The Dynamics of Compensation Peer Benchmarking" Review of Financial Studies, 26(3), 806-839

Frydman, C., and Jenter, D. (2010) “CEO Compensation”, Annual Review of Financial Economics, 2, 75-102.

Gabaix, X. and A. Landier (2008) "Why Has CEO Pay increased so much?" Quarterly Journal of Economics, 123: 49-100. 
Garvey, Gerald and Todd Milbourne (2006) "Asymmetric benchmarking in compensation: Executives are rewarded for good luck but not penalized for bad", Journal of Financial Economics, 82, 197-225

Gibbons, Robert and Kevin Murphy (1990) "Relative Performance Evaluation for chief executive officers" Industrial and Labor Relations Review 43, 30-51

Gompers, Paul, Ishi, Joy and Metrick, Andrew (2003), "Corporate Governance and Equity Prices" Quarterly Journal of Economics, 118, 107-155

Gong, Guojin, Li, Laura Yue, and Shin, Jae Yong (2011) "Relative performance evaluation and related peer groups in executive compensation contracts", Accounting Review, 86, 1007-44.

Gregory-Smith, I., Thompson, S., and Wright, P. W. (2009) "Fired or Retired? A Competing Risks Analysis of Chief Executive Turnover", Economic Journal, 119, 463-81.

Guiso, L., Pistaferri, L., and Schivardi, F. (2005) "Insurance within the Firm", Journal of Political Economy, 113(5), 1054-87.

Hall, B. J., and Liebman, J. B. (1998) “Are CEOs Really Paid like Bureaucrats?" Quarterly Journal of Economics, 113(3), 653-91.

Harford, Jarrad and Kai Li (2007) "Decoupling CEO Wealth and Firm Performance: The case of Acquiring CEOs" Journal of Finance LXII (2) 917-947

Hartzell, Jay and Laura Starks (2003) "Institutional Investors and Executive Compensation", Journal of Finance, 58(6), 2351-74.

Helpman, E., Itskhoki, O., and Redding, S. (2010) "Inequality and Unemployment in a Global Economy", Econometrica, 78(4), 1239-84.

Hermalin, B. and M. Weisbach (2012) "Information Disclosure and Corporate Governance" Journal of Finance, 67(1), 195-233

Holmstrom, Bengt, (1979), Moral hazard and observability, Bell Journal of Economics 10, 74-91.

Holmstrom, Bengt (1982) Moral Hazard in Teams, Bell Journal of Economics 13, 324-340.

Holmstrom, Bengt and Paul Milgrom (1987) "Aggregation and linearity in the provision of inter-temporal incentives" Econometrica, 55, 303-328

Huson, M., Parrino, R. and LT. Starks (2001) "Internal Monitoring mechanisms and CEO turnover: a long-term perspective", Journal of Finance 55, 2265-97.

Jensen, M. C., and Murphy, K. J. (1990) "Performance Pay and TopManagement Incentives", Journal of Political Economy, 98, 225-64.

Jenter, Dirk and Fadi Kanaan (2010) "CEO Turnover and Relative Performance Evaluation" Stanford mimeo

Main, B., O’Reilly, C., and Wade, J. (1993) “Top Executive Pay: Tournament or Teamwork?” Journal of Labor Economics, 11(4), 606-28.

Mas, A. (2016) "Does Disclosure affect CEO Pay setting? Evidence from the passage of the 1934 Securities and Exchange Act", Princeton mimeo

Murphy, Kevin (1999) "Executive Compensation" in Orley Ashenfelter and David Card (eds) Handbook of Labor Economics Volume 3b, Amsterdam: North Holland

Office for National Statistics, Annual Survey of Hours and Earnings, 19972009: Secure Data Service Access Colchester

Ozkan, N. (2009) "CEO Compensation and Firm Performance: An Empirical Investigation of UK Panel Data", European Financial Management

Rosen, Sherwin (1974) "Hedonic Prices and Implicit Markets: Product Differentiation in Pure Competition”, Journal of Political Economy 82 (1), 34-55 
Rosen, Sherwin, (1981) "The Economics of Superstars" American Economic Review, 71(5), 845-58.

Ryan, Harley, and Roy Wiggins (2004) "Who is in whose pocket? Director Compensation, board independence, and barriers to effective monitoring", Journal of Financial Economics, 73(3), 497-524.

Schain, Jan and Joel Stiebale (2016) "Innovation and Institutional Ownership: Comment" University of Dusseldorf, mimeo

Selvaggi, M., and Upton, J. (2008) "Governance and Performance in Corporate Britain", Association of British Insurers Research Paper No.7.

Van Reenen, J. (1996) "The Creation and Capture of Rents: Wages and Innovation in a Panel of U.K. Companies", Quarterly Journal of Economics, 111, 195226. 
FIGURE 1: CEO MEDIAN REAL PAY GROWTH COMPARED TO

TOP 1\% AND MEDIAN PAY GROWTH FOR ALL WORKERS

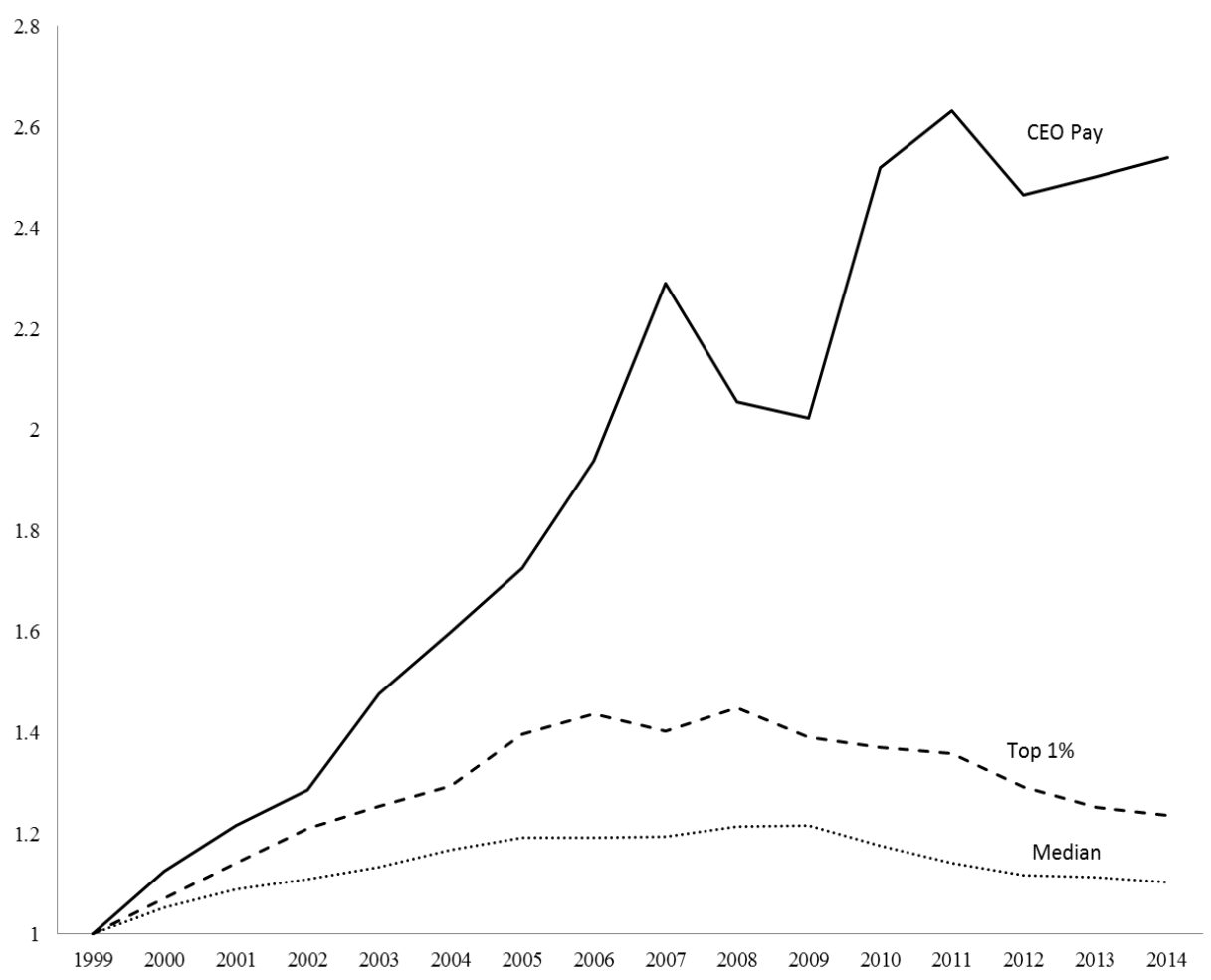

Notes: CEO real median pay is taken from our data (see text), percentiles of pay are from the Annual Survey of Hours and Earnings (ASHE). 2014 prices. Pay rates normalized to 1 in 1999. 


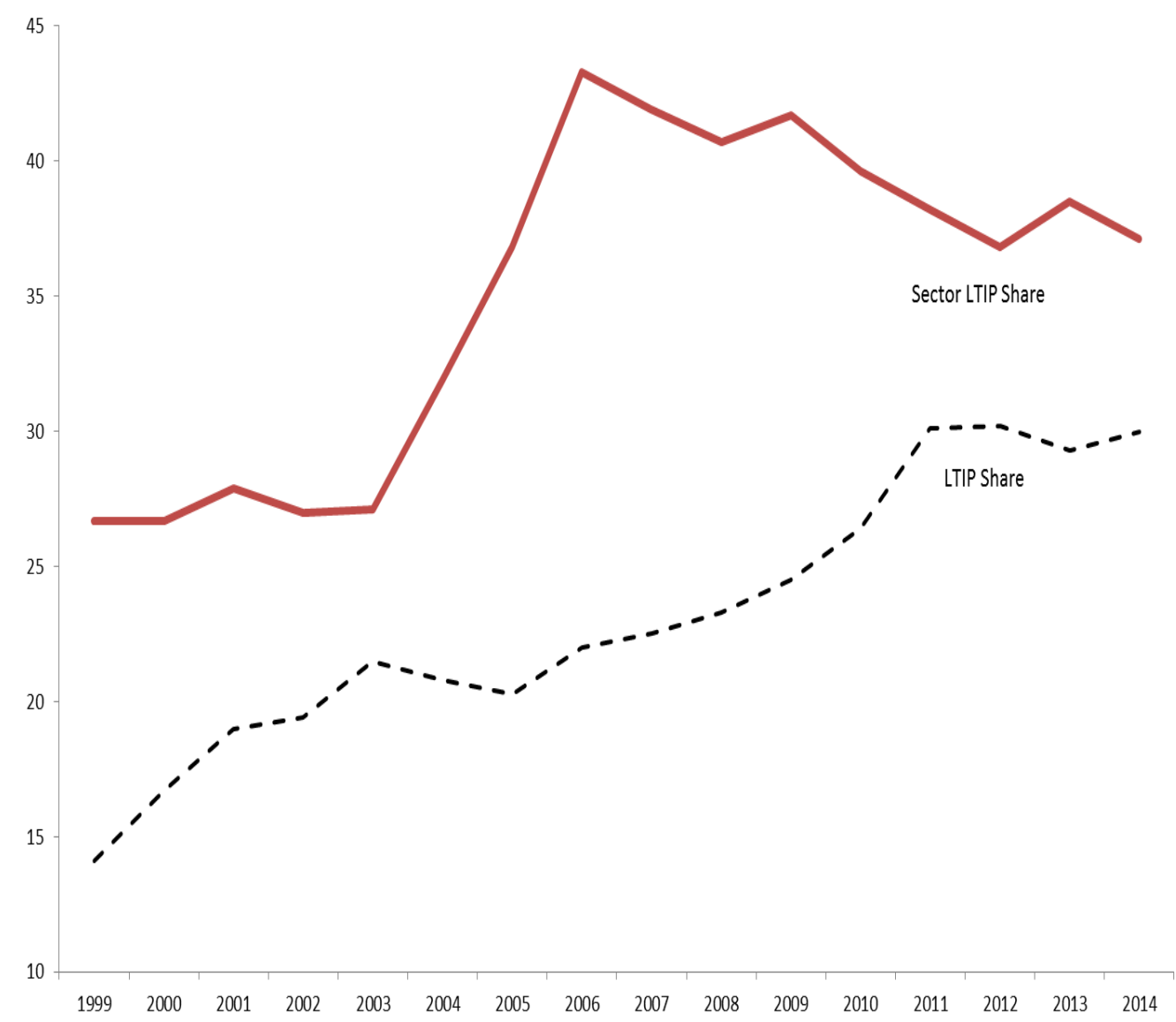

Notes: LTIP share is the estimated proportion of total pay in the form of LTIPs. Sector LTIP Share shows the percentage of all LTIPs that have a sector component in the performance evaluation (i.e. are benchmarked against an industry peer average).

Source: Authors' calculations based on Boardex data 
FIGURE 3. VODAFONE LTIP VESTING SCHEDULE

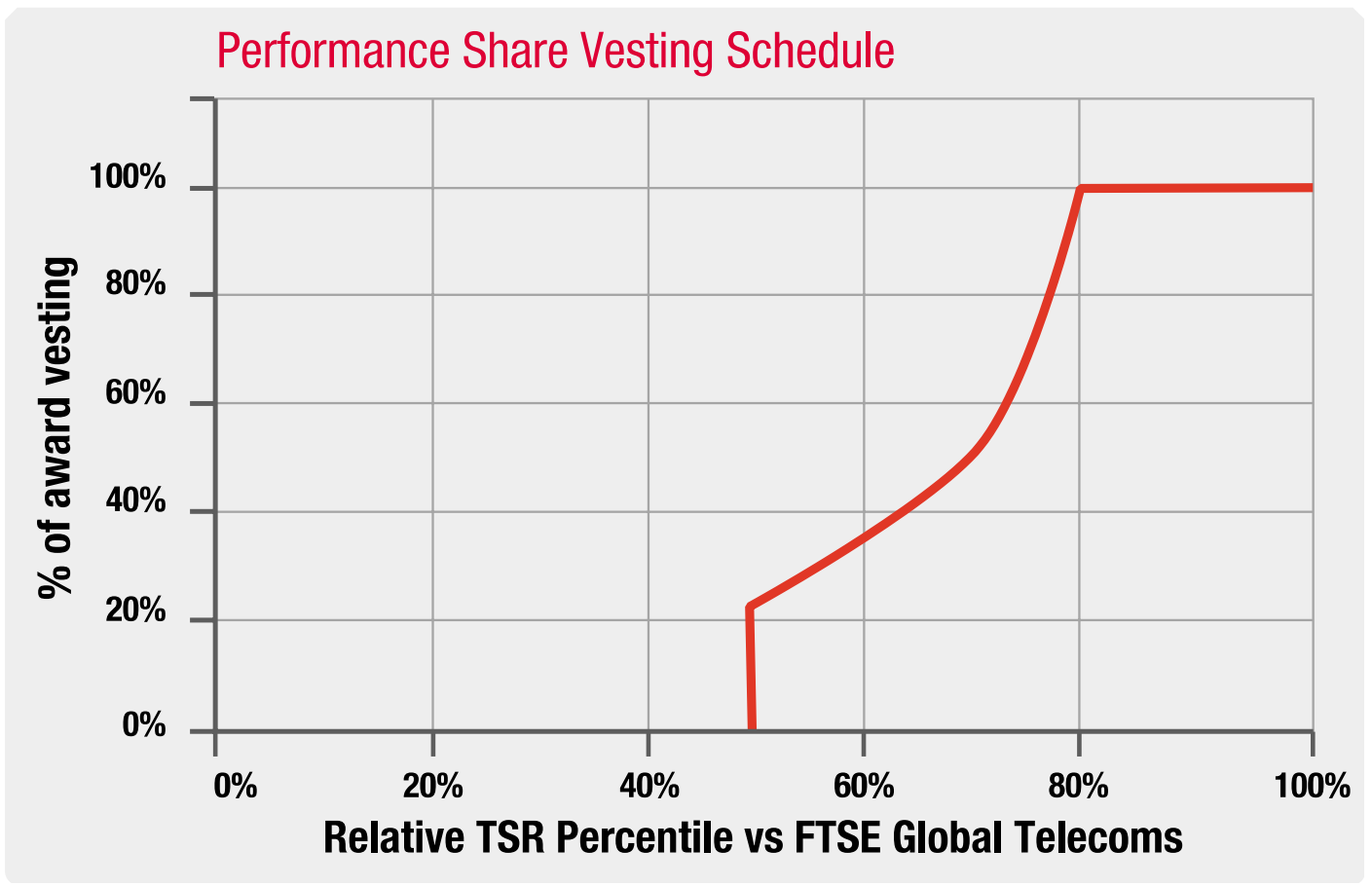

Notes: Taken from Vodafone's 2005 accounts relating to a 2004 LTIP award. Figure indicates the proportion of shares ( 2 million) that will be granted to CEO depending on the performance of Total shareholder Return relative to basket of 28 "peer" telecom companies in the July $28^{\text {th }} 2004$ to July $28^{\text {th }}$ 2007 period. 
Figure 4. ASYMmetric PAy-PERformanCE Estimates

Panel A: Firms with strong governance (High share of Institutional Owners)

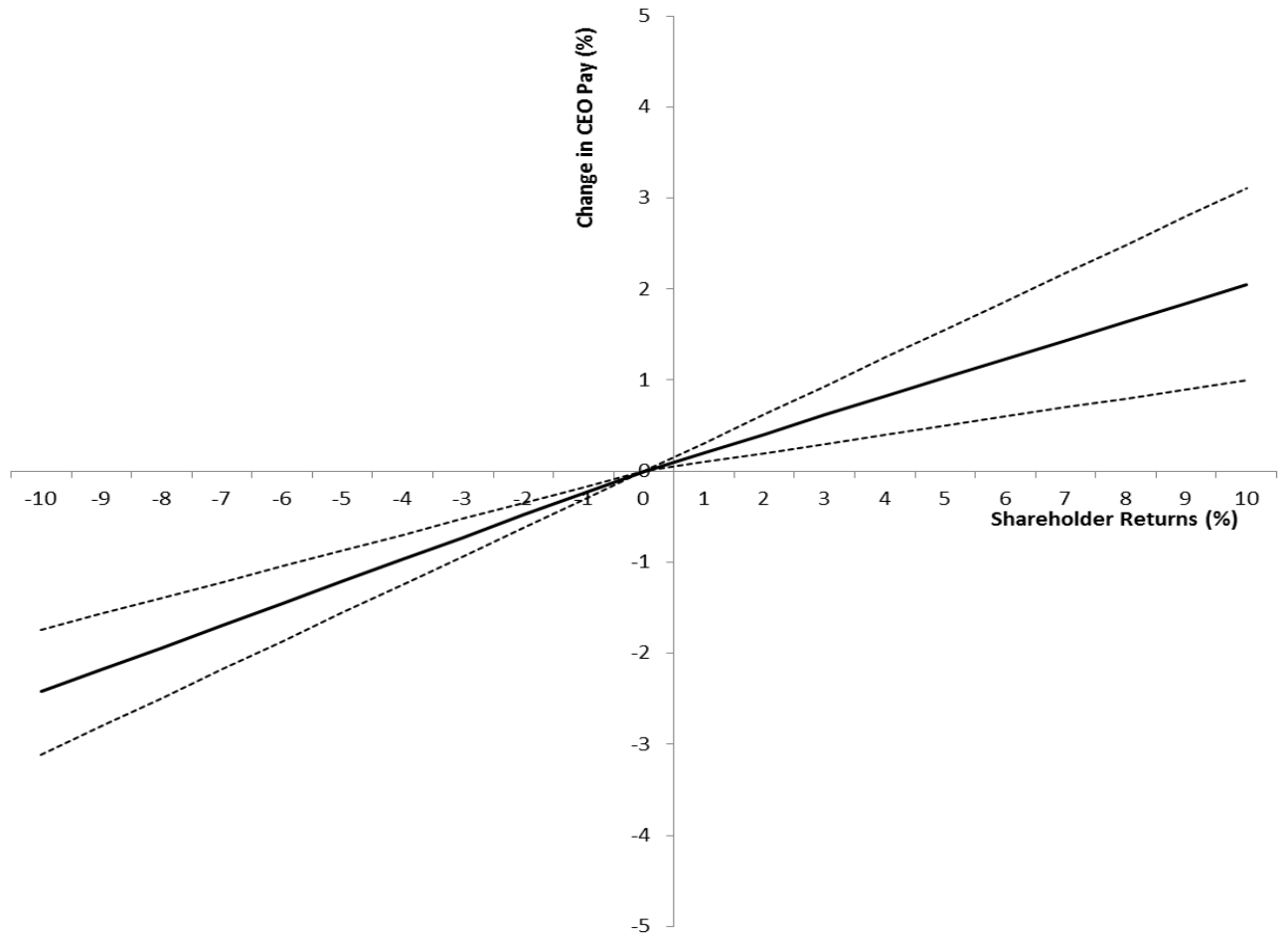

Panel B: Firms with weak governance (Low share of Institutional Owners)

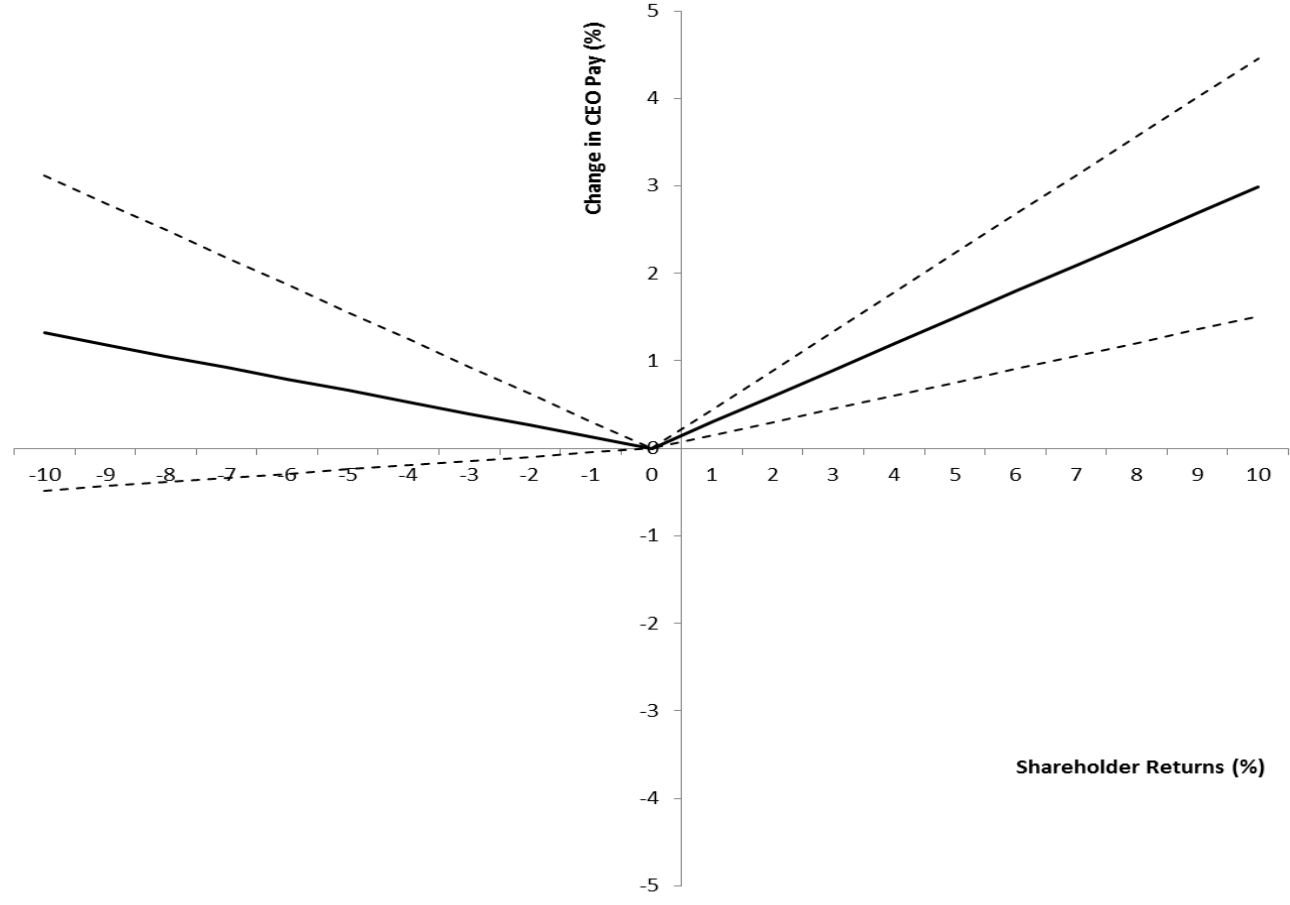

Notes: Theses figures represent the implied effect of a percentage change in TSR (shareholder returns) on the percentage increase in CEO pay. The coefficients are from the specification in column (5) of Table 4. $95 \%$ confidence intervals shown. 
$£ ’ 000$ s

Total Salary Bonus

\section{Compensation}

\section{Boardex Sample}

CEO (obs $=6,090)$

1,638

1,039

539

501

598

Median

1,489

482

262

214

s.d.

285

817

778

\section{Towers Watson Sample}

$\begin{array}{lcccc}\text { CEO (obs = 624) } & 2,581 & 881 & 800 & 900 \\ \text { Median } & 2,122 & 876 & 576 & 638 \\ \text { s.d. } & 1,672 & 259 & 773 & 949 \\ & & & & \\ \text { Level 2 (obs = 3,700) } & 846 & 358 & 238 & 251 \\ \text { Median } & 680 & 334 & 157 & 168 \\ \text { s.d. } & 637 & 160 & 304 & 292 \\ & & & & \\ \text { Level 3 (obs = 8,889) } & 335 & 185 & 86 & 64 \\ \text { Median } & 280 & 172 & 59 & 41 \\ \text { s.d. } & 276 & 72 & 190 & 83\end{array}$

\section{ASHE Matched Sample}

$\begin{array}{lccc}\text { Managers (obs }= & 50 & 42 & 7 \\ \begin{array}{l}\text { l1,193) } \\ \text { Median }\end{array} & 37 & 35 & 2 \\ \text { s.d. } & 53 & 32 & 31 \\ & & & \\ \text { Workers (obs = 96,319) } & 21 & 20 & 1 \\ \text { Median } & 18 & 17 & 0 \\ \text { s.d. } & 16 & 13 & 6\end{array}$

Notes: All figures are in real (2014) £1000s. Data are for 2001-2010 (Towers-Watson), 1999-2015 (Boardex) and 2002-2014 (ASHE). New Equity is the expected value at grant date of new equity awards. Total Compensation is New Pay (the sum of salary, bonus and new equity). 
TABLe 2: ReMUneration AND FiRm PERFORMANCE

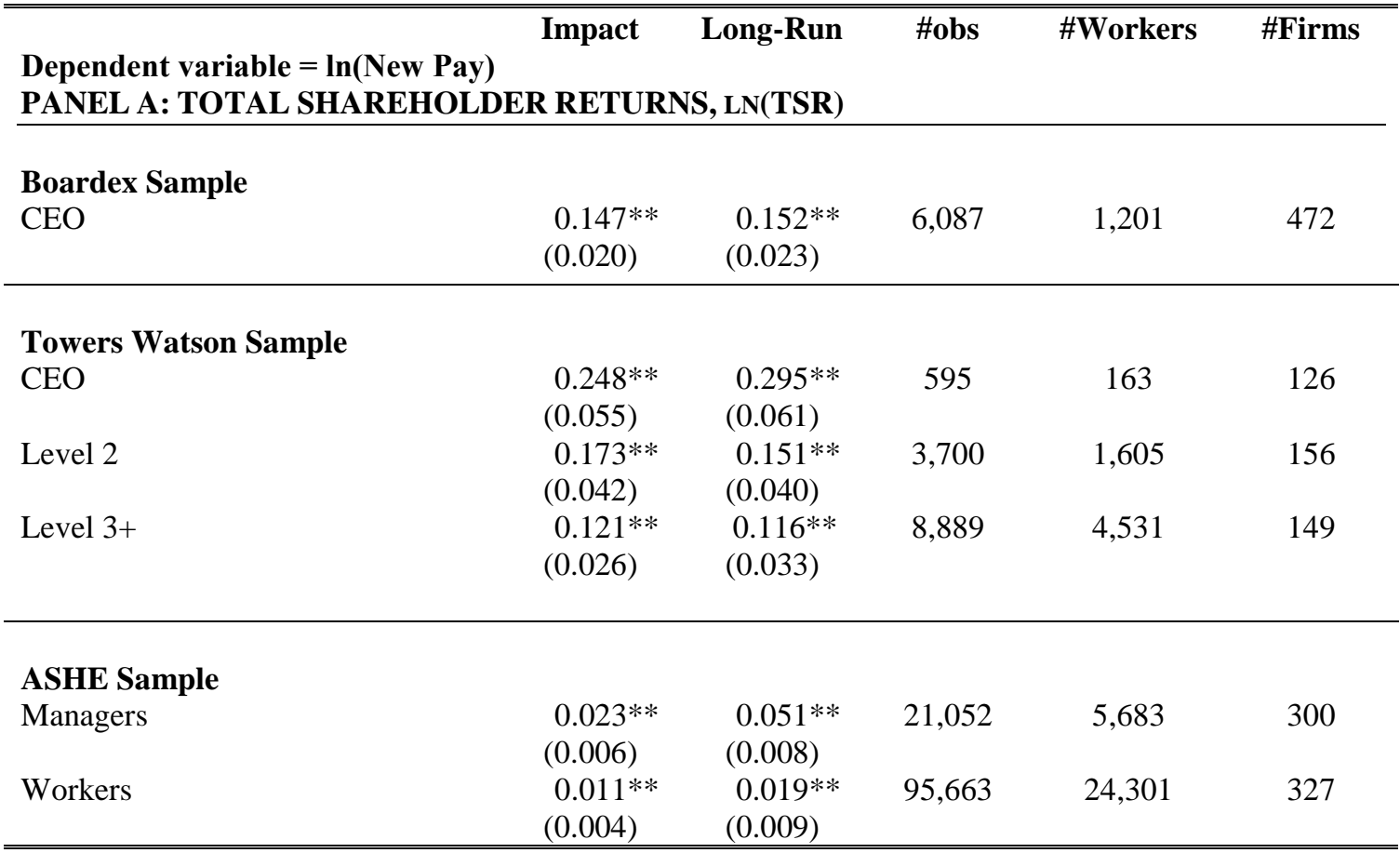

\section{PANEL B: SALES PER WORKER, LN(QUASI-RENTS, QRN)}

\section{Boardex Sample \\ CEO}

$$
0.221 * * \quad 0.247 * *
$$

(0.028)
(0.039)
6,100

1,201

472

\section{Towers Watson Sample}

CEO

Level 2

Level 3+
601

$0.374^{*}$

(0.105)

$0.172 * *$

(0.087)

0.038

(0.038)

$(0.129)$

$0.219 *$

(0.129)

0.037

(0.073)
3,689

1,598

156

8,820

4,486

149

$0.037 *$

$0.047 *$

21,052

5,683

300

Managers

(0.018)

(0.026)

Workers

0.019

0.021

95,663

24,301

327

Notes: $* *$ and $*$ indicate significance at the $5 \%$ and $10 \%$ level respectively. Each row reports the results from a separate OLS regression where the dependent variable is $\ln$ (New Pay) of different types of employees from each of our three pay datasets (Towers Watson, Boardex and ASHE). In Panel A, $\ln (\mathrm{TSR}=$ Total Shareholder Returns) and in Panel B, $\ln (\mathrm{QRN}=$ Sales per worker) is the measure of firm performance used and we report the OLS coefficient and standard error clustered by firm in parentheses underneath. The first column is the "impact" effect that includes only contemporaneously dated performance. Column (2) reports the long-run effect from a regression with both contemporaneous and two lags of performance. All regressions include worker-firm match fixed-effects, $\ln$ (firm employment) and time dummies. ASHE worker regressions also include the average $\ln$ (wage) in the two-digit industry and the average $\ln$ (wage) in the two-digit occupation. ASHE manager regressions also include the average ln(wage) in the two-digit industry. 


\begin{tabular}{lccc}
\hline \hline Dependent variable: & $\begin{array}{c}(\mathbf{1}) \\
\mathbf{L n}(\mathbf{B a s e} \\
\text { Salary) }\end{array}$ & $\begin{array}{c}(\mathbf{2}) \\
\mathbf{L n}(\text { Bonus) } \\
\text { PANEL A: In(Total Shareholder Return) }\end{array}$ & $\begin{array}{c}\mathbf{( 3 )} \\
\text { Ln(New } \\
\text { Equity) }\end{array}$ \\
\hline Boardex Sample & & & \\
CEO & 0.003 & $1.718^{* *}$ & $0.375^{* *}$ \\
& $(0.012)$ & $(0.157)$ & $(0.159)$ \\
& & & \\
\hline Towers Watson Sample & & & \\
CEO & $0.026^{*}$ & $3.786^{* *}$ & $0.682^{* *}$ \\
& $(0.014)$ & $(0.720)$ & $(0.336)$ \\
Level 2 & 0.019 & $2.287^{* *}$ & $0.991^{* *}$ \\
& $(0.014)$ & $(0.751)$ & $(0.343)$ \\
Level 3+ & 0.010 & $1.497^{* *}$ & $0.744^{* *}$ \\
& $(0.007)$ & $(0.485)$ & $(0.397)$ \\
& & & \\
ASHE Sample & & & \\
Managers & -0.012 & $1.363^{* *}$ & \\
Workers & $(0.014)$ & $(0.614)$ & \\
& -0.001 & $0.752^{* *}$ & \\
\hline \hline
\end{tabular}

PANEL B: $\ln ($ Sales per employee) as measure of firm performance

\begin{tabular}{lccc} 
Boardex Sample & & & \\
CEO & $0.107^{* *}$ & $1.275^{* *}$ & $0.554^{* *}$ \\
& $(0.021)$ & $(0.277)$ & $(0.242)$ \\
\hline Towers Watson Sample & & & \\
& & & \\
CEO & $0.103^{* *}$ & 0.384 & 0.501 \\
& $(0.032)$ & $(1.097)$ & $(0.982)$ \\
Level 2 & 0.048 & 0.411 & 0.606 \\
& $(0.042)$ & $(0.770)$ & $(0.571)$ \\
Level 3+ & 0.012 & -0.359 & -0.176 \\
& $(0.012)$ & $(0.476)$ & $(0.476)$ \\
\hline ASHE Sample & & & \\
Managers & & & \\
& 0.010 & $2.055^{* *}$ & \\
Workers & $(0.023)$ & $(1.008)$ & \\
& -0.004 & $1.707^{* *}$ & \\
\hline \hline
\end{tabular}

Notes: $* *$ and $*$ indicate significance at the $5 \%$ and $10 \%$ level respectively. Each cell reports the results from a separate regression where the dependent variable is the $\ln$ (Base Salary) in column (1), $\ln (1+$ Bonus) in column (2) and $\ln (1+\mathrm{New}$ Equity) in column (3) where New Equity is the estimated ex ante value of new equity awards. Each row is based on different types of employees from each of our three pay datasets (Towers Watson, Boardex and ASHE). In Panel A, $\ln (\mathrm{TSR}=$ Total Shareholder Returns) and in Panel B, $\ln (\mathrm{QRN}=$ Sales per worker) is the measure of firm performance used and we report the OLS coefficient and standard error clustered by firm in parentheses underneath. All regressions include employee-firm match fixed-effects, $\ln$ (employment) and time dummies. ASHE worker regressions include two-digit industry $\ln$ (wages) and two digit occupation $\ln$ (wages) controls. 
TABle 4: ASYMmetries in THE CEO PAY-PERFORMANCE RELATIONSHIP AND GOVERNANCE

(1)

(2)

(3)

(4)

(5)

(6)

Dependent Variable $=\ln ($ New Pay $)$

\begin{tabular}{|c|c|c|c|c|c|c|}
\hline Method: & $\begin{array}{l}\text { Within } \\
\text { Groups }\end{array}$ & $\begin{array}{c}\text { First } \\
\text { Differences }\end{array}$ & $\begin{array}{c}\text { First } \\
\text { Differences }\end{array}$ & $\begin{array}{c}\text { First } \\
\text { Differences }\end{array}$ & $\begin{array}{c}\text { First } \\
\text { Differences }\end{array}$ & $\begin{array}{c}\text { First } \\
\text { Differences }\end{array}$ \\
\hline Corporat & ernance & easure: & Lagged II & & Lagged II & IVIS \\
\hline
\end{tabular}

$\ln \mathrm{TSR}$

0.149 **

(0.020)

$\Delta \ln \mathrm{TSR}$

$0.162^{* * *}$

$0.107 * *$

(0.028)

(0.048)

$\Delta \ln \mathrm{TSR}$

*Strong Gov

$0.227 * *$

(0.027)

$0.242 * *$

$0.239^{* *}$

Strong Gov

0.030

$\Delta \ln \mathrm{TSR}$

* Weak Gov

(0.056)

$-0.132$

(0.092)

(0.034)

$\Delta \ln \mathrm{TSR}(+)$

$0.135 *$

(0.077)

$\Delta \ln \operatorname{TSR}(+)$ *

Strong Gov

$\Delta \ln \operatorname{TSR}(+) *$

Weak Gov

Observations

5,038

5,038

449

5,038

449

-0.037
$(0.071)$

$-0.093$

(0.067)

Firms

449

4
$0.430 * * \quad 0.249 * *$
$(0.141) \quad(0.094)$

$\begin{array}{lll}5,038 & 5,038 & 4,959\end{array}$

449

449

466

Notes: ** and * indicate significance at the $5 \%$ and $10 \%$ level respectively. All results use Boardex Data. Column (1) is a fixed-effect model with the $\ln (\mathrm{New}$ Pay) as the dependent variable. The subsequent columns report firstdifference models. Low II firms are those with one-year (or more) lagged institutional investor share ownership in the bottom quartile of the distribution (and High II are all others). IVIS is whether the firm is above or below median in the IVIS index of corporate governance. The index ranges between 2 and 0 depending on the number of "red" (= 2 points), "amber" (=1 point) or blue (=0 points). All regressions include employee-firm match fixed-effects and time dummies (time dummies interacted with the High II dummy in columns (3) and (5) and interacted with low and high IVIS measures in column (6)). Standard errors are clustered at the firm-level. 
(1)

Dependent

Variable:

\section{Panel A: OLS Estimates}

$\ln \mathrm{TSR}$

$0.132 * *$

(0.017)
(2)

$\ln ($ New Pay)
(3)

$\ln ($ Total Pay)

\begin{tabular}{lccc}
\hline Panel B: IV Estimates & & & \\
$\ln \mathrm{TSR}$ & $0.139^{* *}$ & $0.207^{* *}$ & $1.070^{* *}$ \\
& $(0.041)$ & $(0.043)$ & $(0.120)$ \\
& & & \\
\# firms & 471 & 471 & 471 \\
\# CEOs & 1,199 & 1,199 & 1,182 \\
\# Observations & 6,070 & 6,070 & 5,342 \\
First Stage F-stat & 167 & 167 & 129
\end{tabular}

Notes: Boardex Data. ** and * indicate significance at the 5\% and $10 \%$ level respectively. Cash Pay is salary plus cash bonus, New Pay is Cash Pay plus the expected value of newly awarded equity, and Total Pay is New Pay plus the estimated change in the value of previously awarded but still held equity awards. TSR is total shareholder returns. All regressions include employee-firm match fixed-effects, $\ln$ (employment) and time dummies. In Panel B, TSR is instrumented by the ICB Industrial Sub-Sector Global ex-UK index TSR. Standard errors are clustered at the industry level. 
TABLE 6: OLS AND IV ESTIMATES OF LTIP VESTING AND VALUE

(1)

Sector LTIP

OLS
(2)

Sector LTIP

IV
(3)

Non-Sector LTIP

OLS
(4)

Non-Sector LTIP

IV

Panel A: Dependent Variable is Vesting Percentage $($ mean $=0.626)$

\begin{tabular}{|c|c|c|}
\hline$\Delta \mathrm{TSR}$ & $\begin{array}{c}0.233^{*} \\
(0.023)\end{array}$ & $\begin{array}{c}0.077 * \\
(0.041)\end{array}$ \\
\hline
\end{tabular}

$\underline{\text { Panel B: Dependent Variable: Change in Value of LTIP in } £ s ~(m e a n=107,871)}$

$\begin{array}{lcccc}\Delta \text { TSR } & 535,980 * * & 388,293 * * & 449,452 * * & 493,023 * * \\ & (27,070) & (64,716) & (36,246) & (102,713) \\ \text { \# Obs } & & & \\ \text { First Stage F-stat } & 2,054 & 2,054 & 3,780 & 3,780 \\ & & 59 & & 36\end{array}$

Notes: Boardex Data. $* *$ and * indicate significance at the $5 \%$ and $10 \%$ level respectively. Panel A has vesting percentage of the relevant LTIP as the dependent variable while Panel B has the ex-post change in value of LTIP (in $£^{\prime} 000$ s) as the dependent variable. Sector LTIP are all performance-related equity plants that have at least some sector TSR comparison component while non-Sector LTIP are all other equity plants. $\triangle$ TSR is the percentage change in total shareholder returns over the performance evaluation period. Results reported are OLS and IV regressions with time dummies. $\triangle$ TSR is instrumented by the ICB Industrial Sub-Sector Global ex-UK index TSR. Standard errors are clustered at the industry level (92 clusters). 
TABLE 7: HoW SOME CEOS GET COMPENSATED FOR FAILING LTIPS

(1)

(2)

(3)

(4)

(5)

\begin{tabular}{|c|c|c|c|c|c|}
\hline $\begin{array}{l}\text { Dependent } \\
\text { Variable: }\end{array}$ & $\ln ($ New Pay) & Cash Pay & $\begin{array}{l}\text { New Equity } \\
\text { Awards }\end{array}$ & $\ln ($ New Pay) & $\begin{array}{l}\text { New Equity } \\
\text { Awards }\end{array}$ \\
\hline Lagged_LTIP_Fail & $\begin{array}{l}-0.004 \\
(0.015)\end{array}$ & $\begin{array}{c}-506 \\
(19,480)\end{array}$ & $\begin{array}{l}40,490 \\
(29,972)\end{array}$ & & \\
\hline $\begin{array}{l}\text { Lagged_LTIP_Fail } \\
* \text { Low II }\end{array}$ & & & & $\begin{array}{l}0.070^{* *} \\
(0.034)\end{array}$ & $\begin{array}{l}143,486^{\text {*** }} \\
(58,023)\end{array}$ \\
\hline $\begin{array}{l}\text { Lagged_LTIP_Fail } \\
* \text { High II }\end{array}$ & & & & $\begin{array}{l}-0.022 \\
(0.017)\end{array}$ & $\begin{array}{c}9,363 \\
(34,944)\end{array}$ \\
\hline Lagged $\ln \mathrm{TSR}$ & $\begin{array}{l}0.185^{* *} \\
(0.018)\end{array}$ & $\begin{array}{l}113,898 * * \\
(19,770)\end{array}$ & $\begin{array}{l}116,948 * * \\
(51,535)\end{array}$ & $\begin{array}{l}0.187^{* *} \\
(0.021)\end{array}$ & $\begin{array}{l}116,625^{*} \\
(62,363)\end{array}$ \\
\hline $\operatorname{Pr}($ Low II = High II $)$ & & & & $0.016 * *$ & $0.047 * *$ \\
\hline \# Obs & 5,070 & 5,070 & 5,070 & 5,070 & 5,070 \\
\hline \# CEOs & 1,049 & 1,049 & 1,049 & 1,049 & 1,049 \\
\hline \# Firms & 449 & 449 & 449 & 449 & 449 \\
\hline
\end{tabular}

Notes: Boardex Data. ** and * indicate significance at the 5\% and 10\% level respectively. New Pay is Cash Pay plus the expected value of newly awarded equity and New Equity Awards is the expected $£$-value of new equity awards on grant date. Lagged_LTIP_Fail equals one if the LTIPs that vested in the previous financial year did not fully vest, and zero otherwise. TSR is total shareholder returns and is included in all columns. High II is equal to one if the firm's lagged institutional ownership share is in the top three quartiles across all firms in a given year. Columns (4) and (5) also includes High II interactions with both lnTSR and time dummies Regressions also include the lagged dependent variable to capture persistence in awards. Standard errors are clustered at the firm level. 


\section{APPENDIX A: DATA}

\section{Sampling Frame}

The sample of firms is constructed by ranking all UK-domiciled and UK primary-listed companies by market capitalisation at end-December every year from 1999 to 2010 . We exclude investment trusts. The top 300 firms are selected and over the whole period this produces a sample of 498 firms. On average, the top 300 firms each year represent $94 \%$ of total market capitalization. These firms are then matched to share-price and annual accounts data in Datastream. We are able to match 486 of the firms.

\section{The Boardex Sample}

The 486 firms with share-price and accounts data are then matched to executive-level compensation data from Boardex. We have a flat-file from Boardex containing all executives of UK companies over the period 1999-2014. We are able to match all 486 firms, but only 472 have pay data in Boardex. The Boardex coverage increased substantially from around 2002 and has subsequently covered almost all listed UK companies. Across all matched companies, we have 1,201 CEOs with at least two years of pay data.

\section{The Towers-Watson (TW) Sample}

The Towers-Watson (TW) sample comes from the annual Executive Compensation Survey conducted by TW. The data cover up to five "layers" of management. Level 1 are CEOs and Executive Chairmen. Level 2 are all executives who have a direct reporting line to a Level 1 executive. Level 3 executives report directly to Level 2 executives and so on down the hierarchy. The pay data is substantially more detailed than normally provided. All the TW firms used are also in the larger Boardex sample.

To create a panel of executives we need to link job holders over cross-sections. The Survey asks for the initials of the job holder each year but these are not provided to us for confidentiality reasons. Instead a random number generator was used to create a 10digit number that is unique for any set of worker initials. We match over adjacent crosssections using this identifier, company name, year of hire and base salary (each survey asks for the prior year base salary of the individual as well as current base salary). In this way we create a panel of senior managers over time within a firm, allowing for promotions/demotions. However we cannot identify any workers who move from one firm to another in this sample.

\section{The Annual Survey of Hours and Earnings (ASHE) Sample}

For each company in the Boardex sample, we have matched a DUNS number. The DUNS number is issued by Dun and Bradstreet and there can be multiple DUNS numbers within a single listed company. We use the number that matches the legallylisted entity. The ONS Annual Respondent Database (ARD) links DUNS numbers (called "egrp_ref" by ONS) to individual firms within the company (identified by the employer reference variable "entref"). There can be multiple entref's for a given egrp_ref. Of the 472 companies in the Boardex sample, we are able to link to 401 in the ARD.

From 2002 onward, the Annual Survey of Hours and Earnings contains an enterprise reference number ("entref") for every worker. Thus we are able to link these to the 
associated DUNS number via the ARD. Of the 401 companies that have a BoardexARD match, we are able to link to 376 in ASHE.

\section{Firm Performance Measures}

Total Shareholder Return (TSR) is a return index. It includes the change in the share price but also incorporates dividends, share buy-backs, M\&A activity, etc. Since it is an index, we also control for firm effects in one way or another to track changes in the index. Source: Datastream.

Quasi-rents are the sales per worker in the firm less the outside wage. Rather than directly deducting off a measure of the outside market wage we do this implicitly by including controls in different ways in the regressions. In the CEO regression the presence of time dummies reflects the evolution of the market wage. We also experimented with including industry dummies interacted with time, which produced similar results. For ASHE we calculate the average $\ln$ (wage) in the occupation by year cell and also the average $\ln$ (wage) in the industry by year cell. Source: Datastream

\section{Other measures}

Employment is the firm's global employment.

\section{Construction of the CEO Pay Variable}

For the main Boardex CEO data, we construct three measures of CEO pay that reflect increasingly broad concepts, with successive measures adding to the previous measure. When discounting the value of new awards that have a vesting period to evaluate in present value terms, we discount by $5 \%$ pa. This figure captures both the probability that the CEO will leave the company prior to the vesting date (and not be entitled to the vesting of the award) and the time value of money.

\section{(i) Cash Pay}

The cash parts of CEO compensation are simply the salary plus the annual bonus. The annual bonus can comprise both a cash bonus and a deferred bonus. A deferred bonus is the promise of shares (or cash) at a point in the future, with no future performance conditions. These are valued at the grant date share price and discounted to be in present value terms, but are otherwise the same as cash. Restricted stock is included in this category - stock that is given to the CEO but cannot be sold for a period of time (this is rare in the UK). We do not account for pensions and other non-pay benefits, due both to complexity and a lack of uniform reporting across firms.

\section{(ii) New Pay}

New Pay measures the flow of new compensation to the CEO in a given year. It therefore combines Cash Pay with the expected value on grant date of any new equity awards. New Equity awards can be further divided into regular stock options and LTIPs (which themselves can be either share-based or option-based). Regular stock options are valued according to Black-Scholes in the standard way, and we can denote their value as $V_{-} O P T$. We use a $5 \%$ interest rate and the trailing 36-month standard deviation of returns in the option calculation. The LTIP aspect is more complicated to calculate. Suppose a CEO receives a set of LTIP awards in the current financial year. We need to construct an expected value for these awards. Consider the following: 


$$
E_{t}\left\{\sum_{k} \phi(t, \tau) \omega_{k \tau} \mathrm{v}_{k \tau}\right\}
$$

where $E_{t}$ is the expectations operator at time $t$. There are a number of plans that the CEO is awarded at time $t$ which potentially vest at different times in the future $\tau, \tau>\mathrm{t}$. Denote the set of different plans as $k$ which will be (potentially) received by the CEO. The value at time $\tau$ of these plans is $\mathrm{v}_{k \tau}$ if the CEO receives it (so for LTIP options this is just $V_{-} O P T$ evaluated at date $\tau$ ), while for LTIP shares this will be a number of shares, $S_{k \tau}$ multiplied by the expected share price, $p_{k \tau}$. We have to form a probability of the CEO receiving each LTIP, which we denote ${ }_{k}$. The plans have to be discounted to period $t$ by the factor $\phi(t, \tau)$ to convert to present value terms. So a typical sharebased LTIP will be valued at:

$$
E_{t}\left\{\sum_{k} \phi(t, \tau) \omega_{k \tau} S_{k \tau} p_{k \tau}\right\}
$$

We know $S_{k \tau}$ from the plans themselves and we assume share prices follow a random walk so that $E_{t} p_{\tau}=p_{t}$. The discount rate is based on the real interest rate. The probability of the plan vesting $\left({ }_{k}\right)$ is harder to calculate, so we will discuss this in more detail below.

A typical LTIP will be a number of shares granted in three years' time if the TSR of the firm is in the top quartile of a company portfolio of a firm's "peers" (say other large oil and gas firms for a company like BP or even the FTSE-100 index as a whole). There will be a smaller fraction of shares awarded if the company is above the median but below the lower quartile (usually a linear schedule) and usually no shares if the company is below median performance. Other LTIP plans include:

- Stock options given conditional on performance (instead of shares or granted unconditionally like standard options).

- Cash granted conditional on performance (much rarer as the bonus is usually based on subjective performance evaluation)

- Relative performance based on a market index like the FTSE-100

- An absolute performance target (usually some improvement in the firm's own TSR irrespective of other firms' TSR)

- A target specified in accounting terms instead of TSR (e.g. earnings per share, EPS)

One strategy would be to estimate the expected vesting probability based on detailed knowledge of the plan's structure and analyst forecasts of the firm's expected performance. This is what is done by the analysts in the Towers-Watson data. For the Boardex data this is infeasible as each scheme is sufficiently complicated to prevent the construction of a database that could generate such predictions. We therefore follow a second simpler strategy, which is to use the empirical proportion of success for all firms in the sample. To achieve this, we have taken every equity award given to a CEO in our 
sample and followed the award through to vesting outcome (firms are required to report this in the remuneration report). This then allows us to calculate the average percentage of shares that vest. Table A1 reports the realised outcome of awards across the complete sample.

In effect, we assume that the firm has full information about the future state of the market, but not the firm's own idiosyncratic success. We therefore assume that on grant date, all awards are expected to vest in the same percentage as all such awards of that type have done historically. So for example, if a CEO is awarded an LTIP Share award, we assume that the ex-ante vesting percentage is $52.5 \%$. We also look at other probabilities such as considering only past information on vesting probabilities and not future information, using industry-specific probabilities, etc. The results are robust to these alternatives.

Note that we do not explicitly account for the possibility that the CEO exits over the lifetime of the LTIP. The provisions over what the CEO would obtain if he left are very complex (Golden Parachutes, etc.) and depend on whether the departure is voluntary or not ("good leaver" or not). However, the fact that we build in forfeiture from the empirical vesting probabilities across the whole sample (which includes exits), helps to mitigate this issue.

\section{(iii) Total Pay}

Since LTIPs are usually granted every year, the CEO will generally have a portfolio which are due to vest at different times. One can therefore argue that the total remuneration that a CEO receives in a given year is equal to the New Pay received plus the change in the value of all LTIPs received in previous years that have not yet vested and been exercised. In terms of the expected value of LTIPs presented above, we need to calculate the change in expected value from one period to the next:

$$
E_{t+1}\left\{\sum_{k} \phi(t+1, \tau) \omega_{k \tau} S_{k \tau} p_{\tau}\right\}-E_{t}\left\{\sum_{k} \phi(t, \tau) \omega_{k \tau} S_{k \tau} p_{\tau}\right\}
$$

So for any award that has still not reached its vesting date $\tau$ at time $t+1$, we need to evaluate the above expression. The number of shares $S_{k \tau}$ does not change (this is set at the grant date) and the market price of the shares is observed at $t$ and $t+1$. The discount factor will simply adjust for the fact that the award is one year closer to vesting and therefore valuable in present value terms. The key difficulty is that the expected vesting probability will have changed i.e. $E_{t+1} \quad k \quad E_{t} \quad k$

We take the following approach to this problem. Since we know what happens to the LTIP eventually (our sample period ends in 2015 so we do not know what happens to recently granted awards), we construct expectations of the vesting probability from the date of grant (when they are set according to Table A1) to the date of vesting such that the expected probability moves smoothly from the initial expected value to the realised outcome. Suppose for example that an LTIP share award is given that ultimately vests with only $30 \%$ of shares awarded after three years. We start with a vesting probability of 0.525 , after year one this is reduced to 0.45 , after year two it is reduced to 0.375 and 
reaches the actual vesting outcome of 0.3 at the end of year three. This then provides all the data we need to calculate the change in expected value of previous LTIPs. ${ }^{34}$

\section{Appendix B: Models of Pay And Performance}

The standard competitive model predicts that long-run wages should depend on a worker's skills, both observed and unobserved, but not on the performance of the firm. ${ }^{35}$ However in more realistic settings, we might expect to observe a positive correlation between wages and firm performance - e.g. standard bargaining models predict such a link. $^{36}$

To be more concrete, consider two models of wage determination that generate links between firm performance and wages. First, suppose we have a model in which wages are determined by Nash Bargaining, with $\theta$ measuring the bargaining power of employees. Note that $\theta$ can vary across employees so that some employees - e.g. senior managers may have more bargaining power. The maximisation problem is simply:

$$
\max [\theta \ln \{[u(w)-u(\bar{w})] n\}+(1-\theta) \ln V]
$$

where $u(w)$ is the worker's utility from wage $w, \bar{w}$ is the outside wage in the event of a breakdown in bargaining, $n$ is employment and $V$ is the firm's market value (assumed zero if bargaining breaks down). It is easily shown that at an interior optimum, the firstorder conditions imply that:

$$
w \cong \bar{w}+\left(\frac{\theta}{1-\theta}\right) \frac{V}{n}
$$

The equilibrium wage is determined by the outside wage, the relative bargaining strength of the two sides and the firm's market value per employee.

As an alternative, the standard agency model has risk-neutral shareholders trying to induce risk-averse employees (typically senior executives) to maximise shareholder value. With imperfect observability, shareholders cannot contract on actions. Thus they offer a contract that makes pay dependent on the firm's performance. Firm performance depends on the actions of the employee and stochastic factors, $u, u$ $\sim N\left(0, \sigma^{2}\right)$. Holmstrom and Milgrom (1987) derive the optimal incentive scheme, $w$, for this model. Since shareholders can only observe $V$, this is all the incentive scheme can depend on. So,

$$
w=\alpha+\beta V
$$

\footnotetext{
${ }^{34}$ Note that this is different from the "ex ante" compensation used in the Execucomp TDC1 commonly used by researchers in the CEO pay literature. TDC1 uses an ex ante evaluation of stock option grants using the Black Scholes formula (unlike TDC2 which is the ex post exercise price of stock options) and adds this to all forms of cash compensation. We follow this procedure too. However, TDC2 uses the ex post realisation of all other forms of LTIPs, implicitly valuing all LTIPs at zero until their pay-out. By contrast, we try to treat all other LTIPs symmetrically with stock option and give them a value after they are granted as they are valuable to CEOs and potentially a way of aligning incentives. The reason for the asymmetry in Execucomp is presumably because US firms were not obliged to disclose their non-stock option LTIPs prior to a change in SEC rules in 2006 (see De Angelis and Grinstein, 2016).

${ }^{35}$ Firm characteristics should only matter if they affect compensating differentials for workers (e.g. Rosen, 1974).

${ }^{36}$ Another example is the recent work on firm heterogeneity, trade and wages, in which more productive firms screen more intensively, hire more able workers and pay higher wages. The differences in firm characteristics are systematically related to export performance, as exporters are larger and more productive (e.g. Helpman, Itskhoki and Redding, 2010).
} 
If we assume that the worker has exponential utility, $U(w, e)=-\exp [r(w-c(e))]$, where $r$ is absolute risk aversion and $c(e)$ is the convex disutility of effort, the optimal sharing rate is simply (see Murphy, 1999):

$$
\beta=\frac{1}{1+r \sigma^{2} c^{\prime \prime}}
$$

From our perspective, the important implications of this sharing rule are that $\beta$ is declining for more risk-averse workers $(\partial \beta / \partial r<0)$ and where there is more noise in the relationship between worker effort and firm performance $\left(\partial \beta / \partial \sigma^{2}<0\right)$. Both of these effects seem likely to be more important for more junior employees. Thus we might expect $\beta$ to be larger for CEOs than more junior workers. ${ }^{37}$

\section{APPENDIX C: FURTHER RESULTS}

\section{Pay-performance sensitivities across firms of all size classes}

Are the small pay-performance elasticities we observe in Table 2 for workers merely a result of focusing on a select group of large, quoted companies? To assess this, we estimate quasi-rent sharing models across the population of all firms rather than the large listed firms analysed here. The Annual Respondent Database (ARD) reports sales and employment data for every UK firm, both public and private. This data can be linked to ASHE for the period 2002-2008 resulting in a sample of about half a million worker-year observations. ${ }^{38}$ The results of this exercise are shown in Table A2. For this larger sample of we estimate an elasticity of 0.007 , which is actually smaller than that reported in Table 2. Interestingly this elasticity is almost identical to the OLS estimate for Italian workers using a very similar estimating model reported by Card et al. (2014) who obtain an elasticity of 0.008 for value-added per worker. ${ }^{39}$ Focusing on the Boardex/ASHE sample of companies in Panel B that have both global accounts measures of quasi-rents and UK-only measures from the ARD, we see no substantial difference in the coefficient on productivity.

\section{Has "rent-sharing" declined over time for ordinary workers?}

Has the elasticity between performance and pay for non-CEO employees declined over time? To examine this we first replicate and extend the rent-sharing study of

\footnotetext{
${ }^{37}$ This is the argument in Guiso, Pistaferri and Schivardi (2005). The optimal insurance contract will likely protect ordinary workers more on the downside than senior executives.

${ }^{38}$ It should be noted that the measurement of quasi-rents is not identical to that in Table 2. The ARD only measures sales and employment in the UK, while the sales and employment data used in Table 2 comes from the firm's annual accounts and therefore covers the firms' global totals. We might expect this difference to matter more for our quoted companies since they generally have extensive overseas operations.

${ }^{39}$ If we examine the rent-sharing elasticity for various sub-groups it is clear that the effect is larger for very small companies. Thus the small elasticity we find with respect to quasi-rents for workers appears a general phenomenon for all those working for medium and large-size companies, rather than a result of our particular sampling frame.
} 
Blanchflower, Oswald and Sanfey (1996). They used panel from US manufacturing over 1964-85 to show that a rise in a sector's profitability was followed by an increase in individual wages. They control for worker characteristics such as education and experience by matching the CPS. The estimated long-run elasticity between pay and performance is $0.068 .{ }^{40}$ Following the same procedures we put together data 1964-2005 that allows us to split the sample period into 1964-85 (their estimation period) and 1986$2005 .^{41}$

In Table A3 we report estimates for annual log earnings regressions. Column (1) reports the estimates from Table IV of Blanchflower et al. (1996), column (2) reports the same specification over the first half of our sample and column (3) estimates the same model over the latter half of our sample. Although our replication in column (2) finds broadly similar and significant rent-sharing effects as Blanchflower et al. (1996) over the 19641985 period, there are no such effects over the later period 1986-2005. This suggests that for the average worker, the "rent sharing" parameter has essentially disappeared. We also estimated the model using data on hourly log earnings for production workers from the NBER Productivity Database. ${ }^{42}$ These results are in the last three columns of Table A3. The long-run elasticity for the first half of the sample (0.054) is remarkably close to the estimate in column (1), but again, any rent-sharing seems to have vanished since then, with an estimated long-run elasticity of precisely zero. These findings suggest that rent-sharing, at least for US workers, have become less important.

\section{Pay-for-Luck Simulation}

In Section IV.A we discuss a potential reform of sector LTIPs that would remove any pay-for-luck element. A simple simulation further demonstrate how our results can occur and to understand how LTIPs could be structured to remove the pay-for-luck element. Suppose a firm awards its CEO a sector LTIP with a $£ 3 \mathrm{~m}$ face value. The vesting of these LTIPs depends solely on TSR relative to the sector over the three years.

In our simulation, there are 100 firms in the sector, and performance below the median results in forfeiture. At the median, $25 \%$ of the shares vest, at the $75^{\text {th }}$ percentile all the shares vest, and between the median and the $75^{\text {th }}$ percentile there is a linear vesting schedule. For simplicity, assume sector returns are drawn from a normal distribution with mean 0 and standard deviation $(\mathrm{sd})=20$, while firm returns equal sector returns plus an idiosyncratic return drawn from an independent normal with mean 0 and sd $=$ 5. Such assumptions ensure that there is a distribution of firm returns and that sector shocks are more important than firm shocks. We simulate CEO pay under such a pay regime 1,000 times. The simulation gives us data on realised pay and firm and sector returns. Thus we can essentially duplicate the calculations in Table 6 for these simulated CEO pay packages. In addition, suppose we define a pure sector LTIP as having the same structure as the normal sector LTIP except that the increase in value of the LTIP

\footnotetext{
40 This is calculated from the estimated semi-elasticity and the mean of profits per worker.

${ }^{41}$ Data on wages, hours and worker characteristics come from the CPS March Annual Demographic file and profits per worker come from the NBER productivity database.

42 This has the advantage of allowing us to identify 459 consistent four-digit industries rather than the 16 two-digit industries. The disadvantage is that we cannot control for worker characteristics that change over time across industries. The last three columns of Table A1 report the results for this alternative and show similar results to the first three columns (although the wider industrial cross-section improves the precision). Unemployment is these regressions is measured at the two-digit industry level.
} 
is only that part of the firm level return that exceeds the sector average return over the performance period. The vesting rule remains the same.

Table A5 shows the outcome of this simulation. The first two columns give the OLS and IV estimates for the sector LTIP for vesting percentage (panel A) and change in value (panel B) and so are comparable with Table 6 columns (1) and (2) respectively. The simulation replicates the flavour of our results on the real data. Vesting percentages are strongly related to firm returns using OLS but fall (and become insignificant) using IV. But the change in value of the LTIP continues to be closely related in both OLS and IV, with some attenuation of the size of the link in IV. In the final two columns, the results are shown for the pure sector LTIP (the vesting percentage results are omitted as they identical to the standard sector LTIP). In contrast to the previous results, the pure sector LTIP successfully removes sector pay-for-luck both in the vesting percentage and the change in value. 
TABLE A1: REALISED OUTCOME OF EQUITY AWARDS, 1999-2015

\begin{tabular}{lccccc}
\hline \hline & $\begin{array}{c}\text { Number of } \\
\text { Awards }\end{array}$ & $\begin{array}{c}\text { \% Fully } \\
\text { Vesting }\end{array}$ & $\begin{array}{c}\text { \% Partially } \\
\text { Vesting }\end{array}$ & \% Forfeit & $\begin{array}{c}\text { \% of } \\
\text { award } \\
\text { obtained } \\
\text { ex-post }\end{array}$ \\
& & & & & \\
\hline Deferred Bonus & 1,329 & 84.4 & 6.4 & 9.2 & 91.0 \\
$\begin{array}{l}\text { LTIP Share } \\
\text { LTIP Option }\end{array}$ & 3,682 & 31.3 & 35.2 & 33.5 & 52.5 \\
Share Option & 2,702 & 70.1 & 7.5 & 22.4 & 74.7 \\
Other & 1,159 & 80.6 & 2.2 & 17.2 & 82.0 \\
\hline \hline
\end{tabular}

Notes: A unit of observation is a plan (Boardex plus own data collection efforts). Forfeited plans are a mixture of CEOs completely failing to meet the performance criteria and leaving the firm. 
TABLE A2: RENT-SHARING ACROSS THE ENTIRE WORKFORCE

\begin{tabular}{|c|c|c|c|c|}
\hline & OLS & IV & $\begin{array}{c}\text { First-Stage } \\
\text { F-Stat }\end{array}$ & $\begin{array}{c}\text { Sample } \\
\text { Size }\end{array}$ \\
\hline \multicolumn{5}{|c|}{ Panel A: ASHE Complete Sample } \\
\hline All Workers & $\begin{array}{l}0.007 * * \\
(0.001)\end{array}$ & $\begin{array}{c}0.032 * \\
(0.017)\end{array}$ & 15.8 & 498,682 \\
\hline Non-Managerial & $\begin{array}{l}0.005 * * \\
(0.001)\end{array}$ & $\begin{array}{l}0.039 * * \\
(0.019)\end{array}$ & 12.8 & 419,037 \\
\hline Managerial & $\begin{array}{l}0.015^{* *} \\
(0.004)\end{array}$ & $\begin{array}{c}0.019 \\
(0.026)\end{array}$ & 23.5 & 74,697 \\
\hline Manufacturing Firms & $\begin{array}{l}0.017 * * \\
(0.004)\end{array}$ & $\begin{array}{c}0.114 \\
(0.096)\end{array}$ & 1.8 & 88,251 \\
\hline Non-Manufacturing Firms & $\begin{array}{l}0.006^{* *} \\
(0.001)\end{array}$ & $\begin{array}{c}0.036^{*} \\
(0.020)\end{array}$ & 11.4 & 404,271 \\
\hline \multicolumn{5}{|c|}{ Panel B: ASHE-Boardex Sample } \\
\hline Using Global Accounts QRN & $\begin{array}{c}0.009 \\
(0.012)\end{array}$ & $\begin{array}{l}-0.011 \\
(0.086)\end{array}$ & 2.3 & 78,859 \\
\hline Using UK ARD QRN & $\begin{array}{c}0.006 \\
(0.003)\end{array}$ & $\begin{array}{l}-0.031 \\
(0.049)\end{array}$ & 1.3 & 78,859 \\
\hline
\end{tabular}

Notes: The results in this table are for all workers in ASHE that can be matched to an enterprise group in the ARD. They include workers in both publicly-quoted and private companies. The IV estimates use quasi-rents for all firms in the same 4-digit SIC industry (excluding the firm itself) for $\ln \mathrm{QRN}$. We exclude observations in which the firm accounts for more than $95 \%$ of industry sales All regressions include worker-firm match fixed-effects, time dummies and lnEmp, with standard errors clustered at the firm level. The sample period is 2002-2008. ** and * indicate significance at the $5 \%$ and $10 \%$ level respectively. 


\section{TABLE A3: RENT-SHARING IN US MANUFACTURING, 1964-2005}

\begin{tabular}{|c|c|c|c|c|c|c|}
\hline & (1) & (2) & (3) & (4) & $(5)$ & (6) \\
\hline & 1964-1985 & 1964-1985 & $1986-2005$ & $1964-2005$ & 1964-1985 & 1986-2005 \\
\hline $\operatorname{Ln} U_{t}$ & $\begin{array}{l}-0.0108 \\
(0.0120)\end{array}$ & $\begin{array}{l}-0.0097 \\
(0.0082)\end{array}$ & $\begin{array}{c}0.0005 \\
(0.0130)\end{array}$ & $\begin{array}{l}-0.0016^{*} \\
(0.0010)\end{array}$ & $\begin{array}{l}-0.0036^{* *} \\
(0.0018)\end{array}$ & $\begin{array}{c}0.0009 \\
(0.0014)\end{array}$ \\
\hline$(\pi / n)_{t-1}$ & $\begin{array}{l}-0.0015 \\
(0.0022)\end{array}$ & $\begin{array}{c}0.0004 \\
(0.0006)\end{array}$ & $\begin{array}{c}0.0004 \\
(0.0006)\end{array}$ & $\begin{array}{l}0.0014 * * \\
(0.0004)\end{array}$ & $\begin{array}{l}0.0023^{* *} \\
(0.0009)\end{array}$ & $\begin{array}{l}0.0011 * * \\
(0.0005)\end{array}$ \\
\hline$(\pi / n)_{t-2}$ & $\begin{array}{c}0.0031 \\
(0.0025)\end{array}$ & $\begin{array}{c}0.0012 * \\
(0.0007)\end{array}$ & $\begin{array}{c}0.0004 \\
(0.0005)\end{array}$ & $\begin{array}{l}-0.0006 \\
(0.0006)\end{array}$ & $\begin{array}{c}0.0004 \\
(0.0010)\end{array}$ & $\begin{array}{l}-0.0009 * \\
(0.0005)\end{array}$ \\
\hline$(\pi / n)_{t-3}$ & $\begin{array}{c}0.0026 \\
(0.0021)\end{array}$ & $\begin{array}{l}0.0013^{* *} \\
(0.0006)\end{array}$ & $\begin{array}{l}-0.0002 \\
(0.0006)\end{array}$ & $\begin{array}{c}0.0004 \\
(0.0004)\end{array}$ & $\begin{array}{l}0.0022 * * \\
(0.0007)\end{array}$ & $\begin{array}{l}-0.0002 \\
(0.0004)\end{array}$ \\
\hline $\operatorname{Ln} w_{t-1}$ & $\begin{array}{l}0.3979 * * \\
(0.0618)\end{array}$ & $\begin{array}{l}0.2845^{* *} \\
(0.0471)\end{array}$ & $\begin{array}{l}0.2117 * * \\
(0.0529)\end{array}$ & $\begin{array}{l}0.8102 * * \\
(0.0110)\end{array}$ & $\begin{array}{l}0.7602 * * \\
(0.0159)\end{array}$ & $\begin{array}{l}0.6584 * * \\
(0.0147)\end{array}$ \\
\hline $\begin{array}{l}\text { Long Run Elasticity } \\
\mathrm{p} \sum(\pi / n)=0\end{array}$ & 0.068 & $\begin{array}{l}0.039 \\
0.031\end{array}$ & $\begin{array}{l}0.009 \\
0.633\end{array}$ & $\begin{array}{l}0.022 \\
0.039\end{array}$ & $\begin{array}{l}0.054 \\
0.000\end{array}$ & $\begin{array}{l}0.000 \\
0.944\end{array}$ \\
\hline $\begin{array}{l}\text { Personal Controls } \\
R^{2} \\
\mathrm{~N}\end{array}$ & $\begin{array}{c}\text { Yes } \\
0.9960 \\
295\end{array}$ & $\begin{array}{c}\text { Yes } \\
0.9962 \\
348\end{array}$ & $\begin{array}{c}\text { Yes } \\
0.9794 \\
320\end{array}$ & $\begin{array}{l}\text { No } \\
0.9953 \\
19201\end{array}$ & $\begin{array}{c}\text { No } \\
0.9934 \\
10098\end{array}$ & $\begin{array}{l}\text { No } \\
0.9795 \\
9103\end{array}$ \\
\hline
\end{tabular}

Notes: ** and * indicate significance at the $5 \%$ and $10 \%$ level. Personal control variables in columns 1-3 are experience, years of schooling, marital status dummies, race dummies, private sector dummy, and percent female. All unemployment rates $U$ and the dependent variable $w$ (hourly earnings) are in natural logarithms. Profit-per-employee, $\pi / n$, is in levels. All variables, including the dependent variable, are measured as the mean of the observation in a year/industry cell. All regressions include year dummies. Standard errors, clustered by industry, are in

pource: CPS March Files, NBER Productivity Database. Column (1) is from Table IV of Blanchflower, Oswald and Sanfey (1996) 
TABLE A4: COMPARISONS BETWEEN LOW AND HIGH INSTITUTIONAL INVESTOR FIRMS

\begin{tabular}{|c|c|c|c|c|}
\hline & $\begin{array}{c}\text { Mean } \\
\text { (Median) }\end{array}$ & $\begin{array}{c}\text { Low II } \\
\text { Mean } \\
\text { (Median) }\end{array}$ & $\begin{array}{c}\text { High II } \\
\text { Mean } \\
\text { (Median) }\end{array}$ & T-Test of Means \\
\hline Market Capitalization (£m) & $\begin{array}{l}4,411 \\
(764)\end{array}$ & $\begin{array}{l}5,318 \\
(611)\end{array}$ & $\begin{array}{l}4,122 \\
(798)\end{array}$ & 2.96 \\
\hline Sales (£m) & $\begin{array}{l}3,996 \\
(690)\end{array}$ & $\begin{array}{l}4,850 \\
(487)\end{array}$ & $\begin{array}{l}3,721 \\
(775)\end{array}$ & 2.43 \\
\hline Employment & $\begin{array}{l}18,640 \\
(5,183)\end{array}$ & $\begin{array}{l}17,633 \\
(3,101)\end{array}$ & $\begin{array}{l}18,964 \\
(5,815)\end{array}$ & 0.98 \\
\hline 2-yr Sales Growth (\%) & $\begin{array}{c}20.5 \\
(17.8)\end{array}$ & $\begin{array}{c}26.0 \\
(19.4)\end{array}$ & $\begin{array}{c}18.8 \\
(17.4)\end{array}$ & 3.90 \\
\hline 1-yr Lagged Return (\%) & $\begin{array}{c}6.5 \\
(11.2)\end{array}$ & $\begin{array}{c}5.8 \\
(10.1)\end{array}$ & $\begin{array}{c}6.7 \\
(11.4)\end{array}$ & 0.54 \\
\hline 2-yr Lagged Return (\%) & $\begin{array}{c}15.7 \\
(16.5)\end{array}$ & $\begin{array}{c}17.7 \\
(15.6)\end{array}$ & $\begin{array}{c}15.1 \\
(16.7)\end{array}$ & 1.11 \\
\hline CEO Pay (£m) & 1,388 & 1,293 & 1,419 & 1.77 \\
\hline CEO Lagged Pay Growth (\%) & 11.8 & 12.1 & 11.8 & 0.18 \\
\hline
\end{tabular}

Notes: Comparison of means (and medians) between low institutional ownership (lowest quartile) observations and high institutional ownership (other three quartiles). All values are nominal. 


$\begin{array}{llll}\text { OLS IV IV } & \text { OLS }\end{array}$

\section{A: Vesting Percentage}

$\begin{array}{ccc} & 0.532 * * & 0.107 \\ \operatorname{lnTSR} & (0.065) & (0.068)\end{array}$

B: Change in Value (£’000s)

$\begin{array}{llllc}\operatorname{lnTSR} & \begin{array}{c}28,133 * * \\ (1,997)\end{array} & \begin{array}{l}15,370^{* * *} \\ (2,095)\end{array} & \begin{array}{l}16,950^{* *} \\ (2,052)\end{array} & \begin{array}{c}3,383 \\ (2,156)\end{array} \\ & & & & \\ \text { \# Obs } & 1000 & 1000 & 1000 & 1000\end{array}$

Notes: Panel A has vesting percentage of the relevant LTIP as the dependent variable while Panel B has ex-post change in value of LTIP (in $£^{\prime} 000$ s) as the dependent variable. Data is simulated from a model with sector returns generated by a normal distribution, $\mathrm{N}(0,20)$ and firm idiosyncratic returns generated from $\mathrm{N}(0,5)$. ** and * indicate significance at the $1 \%$ and $5 \%$ level respectively.

\section{Table A6: Job-Exit Marginal ProbabiLities}

\begin{tabular}{lcc}
\hline \hline & $(1)$ & $(2)$ \\
& Boardex CEO & ASHE Workers \\
\hline$\Delta \ln$ TSR & $-0.055^{* *}$ & -0.029 \\
& $(0.009)$ & $(0.020)$ \\
Obs & 5,581 & 164,725 \\
\#Firms & 470 & 372 \\
\#Workers & 1,114 & 60,339 \\
\hline \hline
\end{tabular}

Notes: $* *$ and $*$ indicate significance at the $1 \%$ and $5 \%$ level respectively. The coefficients are marginal effects from a probit model of job-exit with time dummies. Standard errors are clustered at the firm level. 